\title{
Functional cytochrome P450 1A enzymes are induced in mouse and human islets following pollutant exposure
}

\author{
Muna Ibrahim ${ }^{1}$ • Erin M. MacFarlane ${ }^{2} \cdot$ Geronimo Matteo $^{2} \cdot$ Myriam P. Hoyeck $^{2} \cdot$ Kayleigh R. C. Rick $^{2} \cdot$ Salar Farokhi $^{2}$. \\ Catherine M. Copley ${ }^{2}$. Shannon O'Dwyer ${ }^{1}$ • Jennifer E. Bruin ${ }^{2,3}$
}

Received: 14 May 2019 / Accepted: 30 August 2019 / Published online: 27 November 2019

(C) The Author(s) 2019

\begin{abstract}
Aims/hypothesis Exposure to environmental pollution has been consistently linked to diabetes incidence in humans, but the potential causative mechanisms remain unclear. Given the critical role of regulated insulin secretion in maintaining glucose homeostasis, environmental chemicals that reach the endocrine pancreas and cause beta cell injury are of particular concern. We propose that cytochrome P450 (CYP) enzymes, which are involved in metabolising xenobiotics, could serve as a useful biomarker for direct exposure of islets to pollutants. Moreover, functional CYP enzymes in islets could also impact beta cell physiology. The aim of this study was to determine whether CYP1A enzymes are activated in islets following direct or systemic exposure to environmental pollutants.

Methods Immortalised liver (HepG2) and rodent pancreatic endocrine cell lines (MIN6, $\beta$ TC-6, INS1, $\alpha$-TC1, $\alpha$-TC3), as well as human islets, were treated in vitro with known CYP1A inducers 2,3,7,8-tetrachlorodibenzo- $p$-dioxin (TCDD) and 3methylcholanthrene (3-MC). In addition, mice were injected with either a single high dose of TCDD or multiple low doses of TCDD in vivo, and islets were isolated 1,7 or 14 days later.

Results CYP1A enzymes were not activated in any of the immortalised beta or alpha cell lines tested. However, both 3-MC and TCDD potently induced CYP1A1 gene expression and modestly increased CYP1A1 enzyme activity in human islets after $48 \mathrm{~h}$. The induction of CYP1A1 in human islets by TCDD was prevented by cotreatment with a cytokine mixture. After a systemic single high-dose TCDD injection, CYP1A1 enzyme activity was induced in mouse islets $\sim 2$-fold, $\sim 40$-fold and $\sim 80$-fold compared with controls after 1, 7 and 14 days, respectively, in vivo. Multiple low-dose TCDD exposure in vivo also caused significant upregulation of Cypla1 in mouse islets. Direct TCDD exposure to human and mouse islets in vitro resulted in suppressed glucose-induced insulin secretion. A single high-dose TCDD injection resulted in lower plasma insulin levels, as well as a pronounced increase in beta cell death.

Conclusions/interpretation Transient exposure to TCDD results in long-term upregulation of CYP1A1 enzyme activity in islets. This provides evidence for direct exposure of islets to lipophilic pollutants in vivo and may have implications for islet physiology.
\end{abstract}

Keywords Diabetes $\cdot$ Drug metabolism enzymes $\cdot$ Islets $\cdot$ Pollutants $\cdot$ Toxicology $\cdot$ Xenobiotics

Electronic supplementary material The online version of this article (https://doi.org/10.1007/s00125-019-05035-0) contains peer-reviewed but unedited supplementary material, which is available to authorised users.

\section{Jennifer E. Bruin}

jenny.bruin@carleton.ca

1 Laboratory of Molecular and Cellular Medicine, Department of Cellular \& Physiological Sciences, Life Sciences Institute, University of British Columbia, Vancouver, BC, Canada

2 Department of Biology, Carleton University, 1125 Colonel By Drive, Ottawa, ON K1S 5B6, Canada

3 Institute of Biochemistry, Carleton University, 1125 Colonel By Drive, Ottawa, ON K1S 5B6, Canada

$\begin{array}{ll}\text { Abbreviations } & \\ \text { 3-MC } & \text { 3-Methylcholanthrene } \\ \text { AhR } & \text { Aryl hydrocarbon receptor } \\ \text { CYP } & \text { Cytochrome P450 } \\ \text { CYP1A1 } & \text { Cytochrome P450 1A1 } \\ \text { CYP1A2 } & \text { Cytochrome P450 1A2 } \\ \text { DMEM-HG } & \text { High-glucose DMEM } \\ \text { HBSS } & \text { Hanks' balanced salt solution } \\ \text { HG } & \text { High glucose } \\ \text { HIER } & \text { Heat-induced epitope retrieval } \\ \text { KO } & \text { Knockout } \\ \text { KRBB } & \text { Krebs-Ringer bicarbonate buffer }\end{array}$




\section{Research in context}

\section{What is already known about this subject?}

- Epidemiological studies have linked environmental pollutants to diabetes risk in humans

- Cytochrome P450 (CYP) xenobiotic metabolism enzymes are mainly induced in the liver following exposure to xenobiotics (such as pollutants) and are not known to play a role in islet physiology

\section{What is the key question?}

- $\quad$ Are CYP1A enzymes induced in pancreatic islets following direct and/or systemic exposure to environmental chemicals?

\section{What are the new findings?}

- CYP1A1 gene expression and enzyme activity are induced in human islets following direct exposure to the environmental chemicals TCDD and 3-MC

- A single high-dose TCDD injection in mice causes profound induction of CYP1A1 enzyme activity in islets for at least 2 weeks. Multiple low-dose TCDD injections also significantly upregulate Cyp $1 a 1$ in mouse islets

- TCDD exposure impairs human and mouse insulin secretion ex vivo and causes beta cell death in vivo

\section{How might this impact on clinical practice in the foreseeable future?}

- Activation of CYP1A1 in islets implies that environmental chemicals directly reach the endocrine pancreas in vivo and therefore may cause local cell injury. Future studies will investigate the long-term impact of environmental chemicals on beta cell function and/or survival rate

$\begin{array}{ll}\text { LG } & \text { Low glucose } \\ \text { MafA } & \text { MAF bZIP transcription factor A } \\ \text { PFA } & \text { Paraformaldehyde } \\ \text { POPs } & \text { Persistent organic pollutants } \\ \text { qPCR } & \text { Quantitative real-time PCR } \\ \text { TCDD } & 2,3,7,8 \text {-Tetrachlorodibenzo- } p \text {-dioxin } \\ \text { WT } & \text { Wild type }\end{array}$

\section{Introduction}

Persistent organic pollutants (POPs) are lipophilic and resistant to degradation, resulting in widespread environmental dispersion and bioaccumulation $[1,2]$. Chronic human exposure to POPs is associated with adverse health outcomes [3-8], including increased diabetes risk [9-25] and clinical measures of poor insulin secretion [26-28]. However, the mechanisms underlying these associations remain poorly understood.

The pancreas is not traditionally considered a target organ for environmental chemicals, yet mounting evidence suggests that pollutants, particularly POPs, may impact beta cell function [26, 29-31]. For example, reduced insulin secretion was observed in isolated islets $24 \mathrm{~h}$ after in vivo exposure to dioxin $(2,3,7,8$ tetrachlorodibenzo- $p$-dioxin; TCDD) $[30,31]$. Dioxin/dioxin- like compounds are a broad class of POPs that act as agonists for the aryl hydrocarbon receptor (AhR), which activates AhR target genes, including CYP1A1 and CYP1A2 [32, 33]. The primary role for cytochrome $\mathrm{P} 450$ (CYP) enzymes is xenobiotic metabolism and detoxification, but the reactive metabolites generated by CYP-mediated oxidation can be highly toxic. These metabolites are generally unstable and act locally to cause oxidative stress and DNA/protein damage [32-34]. Although CYP enzymes mainly act in the liver, non-hepatic CYP enzymes have also been described [35, 36]. Interestingly, non-hepatic tissues typically accumulate substantially lower concentrations of xenobiotics than liver, but can be disproportionately sensitive to their effects. For example, following TCDD administration in mice, TCDD concentrations were 100 times higher in liver than lung, but CYP1A1 activity was two times higher in lung than liver [37]. We hypothesised that CYP enzymes would be inducible in the endocrine pancreas and serve as a useful tool to elucidate whether environmental chemicals directly target islet cells in vivo.

Previous data supported our idea that CYP1A enzymes might be inducible in the endocrine pancreas. A modest increase in CYP1A1 protein was detected by western blot in immortalised MIN-6 beta cells following $24 \mathrm{~h}$ TCDD treatment [38]. 'CYP1A-like' proteins were reportedly induced in pancreas sections from rats following in vivo 3methylcholanthrene (3-MC) exposure, but these data relied on a promiscuous polyclonal antibody [39]. Most notably, 
O-dealkylation of 7-ethoxyrosorufin (EROD), an established assay for CYP1A1 activity, was increased in pancreatic microsomes from 3-MC-injected rats compared with controls [40]. It remains unclear whether CYP1A1/1A2 are upregulated and/or functional in islets, particularly human tissues. Here, we investigated whether CYP1A genes are induced in mouse and/or human islets following direct in vitro exposure to xenobiotics, TCDD and 3-MC, or systemic exposure in vivo. We also used enzyme activity assays to determine whether islets harbour functional CYP1A enzymes capable of substrate metabolism.

\section{Methods}

\section{Cell culture}

HepG2 cells (kindly provided by T. Kieffer, University of British Columbia), an immortalised human liver cell line, were cultured in high-glucose ( $25 \mathrm{mmol} / \mathrm{l})$ DMEM (DMEMHG; \#10-013-CV, Corning, Corning, NY, USA; or \#D6429, Sigma-Aldrich, St Louis, MO, USA) with 10\% (vol./vol.) heat-inactivated FBS (Sigma-Aldrich \#F1051). INS-1 cells (kindly provided by C. Wollheim, University Medical Center, Geneva, Switzerland), an immortalised rat beta cell line, were cultured in RPMI 1640 (Corning \#10-041-CV) with $10 \%$ (vol./vol.) FBS, $50 \mu \mathrm{mol} / 1$ 2-mercaptoethanol (SigmaAldrich), 10 mmol/1 HEPES (\#BP310, Thermo Fisher Scientific, Waltham, MA, USA) and $1 \mathrm{mmol} / \mathrm{l}$ sodium pyruvate (Sigma-Aldrich \#S8636). MIN6 cells (kindly provided by J. Miyazaki, Osaka University Graduate School of Medicine, Osaka, Japan), an immortalised mouse beta cell line, were cultured in DMEM-HG with $10 \%$ (vol./vol.) FBS. $\beta$ TC-6 cells (\#CRL-11506, ATCC, Manassas, VA, USA), an immortalised mouse beta cell line, were cultured in DMEMHG with $15 \%$ (vol./vol.) FBS. $\alpha$-TC3 and $\alpha$-TC1 clone nine cells (kindly provided by T. Kieffer), immortalised mouse alpha cell lines, were cultured in DMEM-HG (SigmaAldrich \#D6429A) with 10\% (vol./vol.) FBS. All cell lines were confirmed to be free of mycoplasma using the MycoAlert Mycoplasma Detection Kit (\#CA11006554; Lonza, Basel, Switzerland).

\section{Mouse islet isolation and culture}

Islets were isolated from mice by pancreatic duct injection with collagenase $(1000 \mathrm{U} / \mathrm{ml}$; Sigma-Aldrich \#C7657) dissolved in Hanks' balanced salt solution (HBSS: $137 \mathrm{mmol} / 1 \mathrm{NaCl}, 5.4 \mathrm{mmol} / 1 \mathrm{KCl}, 4.2 \mathrm{mmol} / 1 \mathrm{NaH}_{2} \mathrm{PO}_{4}$, $4.1 \mathrm{mmol} / 1 \mathrm{KH}_{2} \mathrm{PO}_{4}, 10 \mathrm{mmol} / \mathrm{l} \mathrm{HEPES}, 1 \mathrm{mmol} / 1 \mathrm{MgCl}_{2}$, $5 \mathrm{mmol} / \mathrm{l}$ dextrose, $\mathrm{pH}$ 7.2). Pancreases were incubated at $37^{\circ} \mathrm{C}$ for $12 \mathrm{~min}$, vigorously agitated and the collagenase reaction quenched by adding cold HBSS with $1 \mathrm{mmol} / \mathrm{l}$
$\mathrm{CaCl}_{2}$. The pancreas tissue was washed three times in $\mathrm{HBSS}+\mathrm{CaCl}_{2}$ (centrifuging for $1 \mathrm{~min}$ at $1000 \mathrm{~g}$ in between washes) and resuspended in Ham's F-10 (\#SH30025.01, HyClone, GE Healthcare Bio-sciences, Pittsburgh, PA, USA; or Corning \#10-070-CV) containing $0.5 \%$ (wt/vol.) BSA (Sigma-Aldrich \#10775835001), $100 \mathrm{U} / \mathrm{ml}$ penicillin and $100 \mu \mathrm{g} / \mathrm{ml}$ streptomycin (Corning \#30002CI). Pancreas tissue was filtered through a $70 \mu \mathrm{m}$ cell strainer and islets were handpicked under a dissecting scope to $>95 \%$ purity.

\section{Human islet culture}

Human islets for experiments in Figs. 3a, b, d, e (H216), 3c (H219), 3f-h (H210, H211, H220) and 4d (H215) were obtained from the Ike Barber Human Islet Transplant Laboratory (Vancouver, BC, Canada). Organ donor purity ranged from $60 \%$ to $90 \%$ islets. Human islets for experiments in Fig. 4a-c (R161) were obtained from the Alberta Diabetes Institute IsletCore (Edmonton, $\mathrm{AB}$, Canada) and islet purity was $95 \%$. All human islets were cultured in CMRL medium (Gibco \#11530-037; Thermo Fisher Scientific) with 10\% (vol/ vol) FBS, $100 \mathrm{U} / \mathrm{ml}$ penicillin, $100 \mu \mathrm{g} / \mathrm{ml}$ streptomycin and $2 \mathrm{mmol} / \mathrm{l} \mathrm{L}$-glutamine (Sigma-Aldrich \#59202C). Research with human islets was approved by the Research Ethics Boards at the University of British Columbia and Carleton University. Refer to the electronic supplementary material (ESM) for the Human Islets Checklist.

\section{In vitro cell treatments}

To determine whether CYP1A1 could be induced in islets, we selected doses that are well established to maximally induce CYP1A1 in liver cells without causing toxicity. The upper doses reflect the half maximal inhibitory concentration $\left(\mathrm{EC}_{50}\right)$ for each chemical. Since TCDD is 1000 times more potent than 3-MC [41-43], we used lower doses of TCDD (1-10 nmol/1) compared with 3-MC (100$1000 \mathrm{nmol} / \mathrm{l})$. Adherent cell lines and isolated pancreatic islets (mouse and human) were treated for $48 \mathrm{~h}$ in vitro with $0.1 \mu \mathrm{mol} / 1$ or $1.0 \mu \mathrm{mol} / 13$-MC (Sigma-Aldrich \#46434-2ML-R, $100 \mathrm{ng} / \mu$ l solution in acetonitrile), $1 \mathrm{nmol} / 1$ or $10 \mathrm{nmol} / 1 \mathrm{TCDD}$ (Sigma-Aldrich \#48599, $10 \mu \mathrm{g} / \mathrm{ml}$ solution in toluene) or the appropriate vehicle control (acetonitrile, toluene or DMSO) in culture medium. Medium was refreshed after $24 \mathrm{~h}$. Where indicated, human islets were also treated with $1 \mu \mathrm{mol} / 1$ thapsigargin (SigmaAldrich), a cytokine mixture (TNF- $\alpha, 50 \mathrm{ng} / \mathrm{ml}$, \#510-RT010, R\&D Systems, Minneapolis, MN, USA; IFN $\gamma$, 1000 U/ml, \#213-10156-1AF, RayBiotech, Peachtree Corners, GA, USA; IL-1 $\beta, 10$ ng/ml, \#JM-4128-10, MBL International Corporation, Woburn, MA, USA) or $10 \mathrm{nmol} / 1$ exendin-4 (Sigma-Aldrich \#E7144) 


\section{CYP enzyme activity assay}

Enzyme activity was measured in various adherent cell lines (HepG2, MIN6, $\beta$ TC-6, INS1, $\alpha$-TC1, $\alpha$-TC3) and isolated mouse and human islets using the P450-Glo CYP1A1 Assay (\#V8752; Promega, Madison, WI, USA) and CYP1A2 Assay (\#V8772, Promega). All assays were performed in 96-well white-walled plates with clear bottoms (\#655098; Greiner Bio-One, Kremsmünster, Austria) using the lytic method, as described by the manufacturer. For adherent cell lines, the assay was performed on cells at $70-90 \%$ confluence. For islets, 50 mouse or human islets were handpicked into each well of the 96-well plate.

\section{In vitro glucose-stimulated insulin secretion assays}

To assess beta cell function, 25-50 mouse or human islets per condition were transferred to a pre-warmed $\left(37^{\circ} \mathrm{C}\right) 24$-well plate containing Krebs-Ringer bicarbonate buffer (KRBB) $\left(115 \mathrm{mmol} / \mathrm{l} \mathrm{NaCl}, 5 \mathrm{mmol} / \mathrm{l} \mathrm{KCl}, 24 \mathrm{mmol} / 1 \mathrm{NaHCO}_{3}\right.$, $2.5 \mathrm{mmol} / 1 \mathrm{CaCl}_{2}, 1 \mathrm{mmol} / 1 \mathrm{MgCl}_{2}, 10 \mathrm{mmol} / \mathrm{l}$ HEPES, $0.1 \%$ (wt/vol.) BSA, pH 7.4) with $2.9 \mathrm{mmol} / \mathrm{l}$ glucose (low glucose, $\mathrm{LG}$ ) for a $40 \mathrm{~min}$ pre-incubation at $37^{\circ} \mathrm{C}$. Islets were then transferred to $500 \mu \mathrm{l}$ of LG KRBB for $1 \mathrm{~h}$, followed by transfer to $500 \mu \mathrm{l}$ of KRBB with $16.7 \mathrm{mmol} / \mathrm{l}$ glucose (high glucose, HG) for $1 \mathrm{~h}$ at $37^{\circ} \mathrm{C}$. The LG KRBB and HG KRBB samples were centrifuged, and the supernatant stored at $-30^{\circ} \mathrm{C}$ until use. To measure insulin content, islets were transferred to an acid-ethanol solution of $1.5 \%$ (vol./vol.) $\mathrm{HCl}$ in $70 \%$ (vol./ vol.) ethanol at $4{ }^{\circ} \mathrm{C}$ overnight and then neutralised with $1 \mathrm{~mol} /$ 1 Tris base ( $\mathrm{pH} 7.5$ ) before long-term storage at $-30^{\circ} \mathrm{C}$. Concentrations of human C-peptide (\#10-1141-01; Mercodia, Uppsala, Sweden) and mouse insulin (\#80INSMS or 80-INSMSH; ALPCO, Salem, NH, USA) were measured by ELISA.

\section{Animals}

All mice received ad libitum access to a standard irradiated diet (Teklad Diet \#2918; Harlan Laboratories, Madison, WI, USA) and were maintained on a $12 \mathrm{~h} \mathrm{light/dark} \mathrm{cycle} \mathrm{through-}$ out the study. All experiments were approved by the University of British Columbia or Carleton University Animal Care Committees and carried out in accordance with the Canadian Council on Animal Care guidelines. Prior to beginning experimental protocols, animals were randomly assigned to treatment groups and matched for body weight and blood glucose levels (ensuring that these variables were not significantly different between groups).

Cohort 1 As outlined in Fig. 5a, 8-week-old male C57Bl/6 mice (Jackson Laboratory, Bar Harbour, ME, USA) received a single i.p. injection of corn oil $(25 \mathrm{ml} / \mathrm{kg}$, vehicle control; $n=4), 20 \mu \mathrm{g} / \mathrm{kg}$ TCDD $(n=4), 100 \mu \mathrm{g} / \mathrm{kg}$ TCDD $(n=4)$ or $200 \mu \mathrm{g} / \mathrm{kg}$ TCDD $(n=4)$. Liver was flash frozen in liquid nitrogen and islets were isolated from all mice (as described above) $24 \mathrm{~h}$ after injection.

Cohort 2 As outlined in Figs. 5h, 6a, 8-week-old male C57B1/ 6 mice (Jackson Laboratory) received a single i.p. injection of corn oil $(25 \mathrm{ml} / \mathrm{kg}$, vehicle control; $n=24)$ or $200 \mu \mathrm{g} / \mathrm{kg}$ TCDD $(n=22)$. On days $7(n=9-10$ per group) and $14(n=$ 9-11 per group) following injection, islets were isolated from a subset of mice for ex vivo glucose-stimulated insulin secretion assays ( 25 islets per mouse), RNA isolation ( $150-200$ islets per mouse) and CYP1A enzyme activity assays (50 islets per mouse per assay). Liver was flash frozen in liquid nitrogen on days 7 ( $n=5$ per group) and $14(n=9-11$ per group). Whole pancreas and liver were harvested from a different subset of mice on day 7 ( $n=3$ per group) and stored in $4 \%$ (vol./vol.) paraformaldehyde (PFA) for $24 \mathrm{~h}$, followed by long-term storage in $70 \%$ (vol./vol.) ethanol.

Cohort 3 As outlined in Fig. 5m and ESM Fig. 2a, 8-week-old male $\mathrm{C} 57 \mathrm{Bl} / 6$ mice received multiple i.p. injections of corn oil ( $25 \mathrm{ml} / \mathrm{kg}$, vehicle control) or a low-dose of TCDD ( $20 \mathrm{ng} / \mathrm{kg}$ per day) twice per week. This dose was previously shown to induce CYP1A1 in liver and lung [44, 45]. Furthermore, chronic administration of $46 \mathrm{ng} / \mathrm{kg}$ TCDD per day resulted in circulating TCDD concentrations of $\sim 8.8 \mathrm{pg} / \mathrm{g}$ in rats [44], which is within the range of background dioxin levels reported in the USA $(\leq 10 \mathrm{pg} / \mathrm{g})$ and corresponds to individuals in the upper quartile $(\geq 5.2 \mathrm{pg} / \mathrm{g}$ ) with increased diabetes prevalence [16]. In our study, the first group of mice (Fig. 5m-p; Jackson Laboratory) was treated at the University of Ottawa Roger Guindon Hall vivarium ( $n=5$ control, $n=8$ TCDD); liver was flash frozen and islets were isolated after 2 weeks (i.e. five injections). A second group of mice (ESM Fig. 2) was generated by in-house breeding and then treated in the Modified Barrier Facility at the University of British Columbia ( $n=4$ per group) for metabolic assessment.

Cyp1a1/1a2 double knockout mice Mice with a global deletion of both Cypla1 and Cypla2, originally generated and characterised by D. Nebert [46], were generously provided by F. Gonzalez (University of Cincinnati). Male mice were used for ex vivo experiments with isolated islets (Fig. 7) and as a negative control for CYP1A1 immunofluorescence staining of pancreas and liver tissues (ESM Fig. 1).

\section{Metabolic assessments}

All metabolic analyses were performed in conscious, restrained mice and blood samples were collected via saphenous vein using heparinised microhematocrit tubes at the indicated time points. Blood glucose levels were measured using a handheld glucometer (Lifescan, Burnaby, BC, Canada). 
Body weight and blood glucose levels were assessed weekly or bi-weekly following a $4 \mathrm{~h}$ morning fast. For all other metabolic tests, time 0 indicates the blood sample collected after fasting and prior to administration of glucose or insulin. For GTTs, mice received an i.p. bolus of glucose $(2 \mathrm{~g} / \mathrm{kg}$; Vetoquinol, Lavaltrie, QC, Canada) following a $6 \mathrm{~h}$ morning fast. During the GTT, blood was collected at the indicated time points for measuring plasma insulin levels by ELISA (ALPCO mouse ultrasensitive insulin ELISA, \#80INSMSU-E01). For ITTs, mice received an i.p. bolus of insulin $(0.7 \mathrm{U} / \mathrm{kg}$, Novolin ge Toronto \#02024233; Novo Nordisk Canada, Mississauga, ON, Canada) after a $4 \mathrm{~h}$ morning fast. For all tests, mice from different treatment groups were randomly distributed throughout the experiment to ensure that timing of blood collection was not a factor in our analysis.

\section{Quantitative real-time PCR}

RNA was isolated from cultured cell lines using the RNeasy Mini Kit (\#74104; Qiagen, Hilden, Germany), human or mouse islets using the RNeasy Micro Kit (\#74004; Qiagen) and liver using TRIzol reagent (\#15596018; Invitrogen, Carlsbad, CA, USA) or the Qiagen RNeasy Mini Kit, according to the manufacturer instructions. DNase treatment was performed prior to cDNA synthesis with the iScript gDNA Clear cDNA Synthesis Kit (\#1725035; Bio-Rad, Mississauga, ON, Canada). Quantitative real-time PCR (qPCR) was performed using the SsoFast EvaGreen Supermix (\#1725200; Bio-Rad) or SsoAdvanced Universal SYBR Green Supermix (\#1725271, Bio-Rad) and run on a CFX96 or CFX384 (Bio-Rad). Hprt/HPRT or Ppia/PPIA were used as the reference genes. Data were analysed using the $\Delta \Delta \mathrm{C}_{\mathrm{t}}$ method. Primer sequences are listed in ESM Table 1.

\section{Immunofluorescent staining and image quantification}

Human islets were washed with PBS, resuspended in $4 \%$ (wt/ vol.) PFA and stored overnight at $4^{\circ} \mathrm{C}$. The following day, islets were washed twice with PBS, resuspended in $200 \mu \mathrm{l}$ prewarmed $2 \%\left(\mathrm{wt} / \mathrm{vol}\right.$.) agarose and cooled briefly at $-20^{\circ} \mathrm{C}$. The agarose pellet was resuspended in $4 \%$ (wt/vol.) PFA for $1 \mathrm{~h}$ at room temperature and then transferred to $70 \%$ (vol/vol.) ethanol for long-term storage at $4^{\circ} \mathrm{C}$ until paraffin embedding. Whole pancreas tissue was fixed in $4 \%$ (vol./vol.) PFA for $24 \mathrm{~h}$ and stored in $70 \%$ (vol./vol.) ethanol prior to paraffin embedding.

Paraffin sections ( $5 \mu \mathrm{m}$ thickness) were prepared by Wax-it Histology Services (Vancouver, BC, Canada) or the University of Ottawa Heart Institute Histology Core Facility (Ottawa, ON, Canada). Briefly, slides were deparaffinised with sequential 5 min incubations in xylene $(\times 3), 100 \%$ (vol./vol.) ethanol $(\times 2), 95 \%$ (vol./vol.) ethanol $(\times 1)$ and $70 \%$ (vol./vol.) ethanol $(\times 1)$, and then transferred to PBS for
10 min on a shaker. Heat-induced epitope retrieval (HIER) was performed in citrate buffer $(10 \mathrm{mmol} / 1$ sodium citrate, $0.05 \%$ (vol./vol.) Tween 20, $\mathrm{pH} 6.0$ ) for $10 \mathrm{~min}$ at $95^{\circ} \mathrm{C}$ using the EZ Retriever microwave system (\#MW014-MO; BioGenex, Fremont, CA, USA), unless indicated otherwise below. Slides were transferred to deionised water for a $5 \mathrm{~min}$ rinse and then to PBS for $5 \mathrm{~min}$. Tissue sections were circumscribed with an ImmEdge Pen (\#H-4000; Vector Laboratories, Burlingame, CA, USA) and then incubated at room temperature for a minimum of 30 min with Dako serumfree protein block (\#X090930-2; Agilent, Santa Clara, CA, USA). Next, primary antibodies were diluted as indicated below for each antibody and added to each section; slides were stored in a humid chamber overnight at $4^{\circ} \mathrm{C}$. The following day, slides were washed $3 \times 10 \mathrm{~min}$ in PBS on a shaker and incubated in secondary antibodies for $1 \mathrm{~h}$ in a humid chamber at room temperature, protected from light. Finally, slides were washed $3 \times 10 \mathrm{~min}$ in PBS on a shaker, and then coverslips were mounted with VECTASHIELD HardSet Mounting Medium with DAPI (\#H-1500, Vector Laboratories) for counterstaining.

The following primary antibodies were used in this study: rabbit anti-MAFA (MAF bZIP transcription factor A) (15 min HIER, 1:1000, shared by T. Kieffer), rabbit anti-somatostatin (1:500, Sigma-Aldrich \#HPA019472), rabbit anti-insulin (C27C9, 1:200, Cell Signaling Technology, Danvers, MA, USA; \#3014), mouse anti-insulin (L6B10, 1:250, Cell Signaling Technology \#8138BF) and mouse anti-glucagon (1:1000, Sigma-Aldrich \#G2654). Numerous primary antibodies for CYP1A1 were tested, and these are outlined in ESM Table 2. The following secondary antibodies were used: goat anti-rabbit IgG $(\mathrm{H}+\mathrm{L})$ secondary antibody, Alexa Fluor 594 (1:1000, Invitrogen \#A11037); and goat anti-mouse $\operatorname{IgG}(\mathrm{H}+\mathrm{L})$ secondary antibody, Alexa Fluor 488 (1:1000, Invitrogen \#A11029). All antibodies were diluted using Dako Background Reducing Antibody Diluent solution (\#S302283-2, Agilent).

To measure apoptosis, pancreas and liver sections were stained with the Molecular Probes Click-iT Plus TUNEL Assay using Alexa Fluor 488 dye (Invitrogen \#C10617), according to the manufacturers instructions. Pancreas sections were counterstained with rabbit antiinsulin (C27C9, 1:200, Cell Signaling \#3014) and goat anti-rabbit $\operatorname{IgG}(\mathrm{H}+\mathrm{L})$ secondary antibody, Alexa Fluor 594 (1:1000, Invitrogen \#A11037). No antigen retrieval was used for counterstaining.

For islet morphology quantification, a minimum of eight islets were imaged with an EVOS FL Cell Imaging System (Invitrogen); the islet area, insulin-immuonoreactive area and glucagon-immunoreactive area were measured for each islet using ImageJ software (https://imagej.nih.gov/ij/index.html). Islet cell apoptosis was quantified as the percentage of insulin ${ }^{+}$ and insulin ${ }^{-}$islet cells that colocalised with $\mathrm{TUNEL}^{+}$nuclei. Liver apoptosis was quantified in at least five images per 
mouse and expressed as the percentage of TUNEL ${ }^{+}$cells in the field of view. Images were captured and quantified by a researcher blinded to the treatment groups.

H\&E staining of pancreas and liver tissues was performed using standard protocols by Wax-it Histology Services. Colour images were taken with an Axio Observer 7 microscope (ZEISS, Oberkochen, Germany).

\section{Statistical analysis}

All statistics were performed using GraphPad Prism software (GraphPad Software, La Jolla, CA, USA). Specific statistical tests are indicated in the figure legends. For all analyses, $p<0.05$ was considered statistically significant. Data are presented as mean \pm SEM, unless indicated otherwise.

\section{Results}

\section{TCDD levels in pancreas decline slower than other tissues in vivo}

To determine how much TCDD reaches the pancreas, we used data from a biodistribution study that measured TCDD tissue concentrations after TCDD administration in mice [37]. After 7 days, the TCDD concentration in pancreas was 72 times lower than liver and 23 times lower than adipose, but higher than other non-classical target tissues (Fig. 1a). However, TCDD levels declined slower in the pancreas than all other tissues (Fig. 1b, d). In liver, TCDD levels were 72 times higher than pancreas 7 days after $10 \mu \mathrm{g} / \mathrm{kg}$ TCDD administration, but only 17 times higher after 35 days (Fig. 1c), and this gap diminished further at lower doses. On day 35, TCDD levels were only five times higher in liver than pancreas after a $1.0 \mu \mathrm{g} / \mathrm{kg}$ dose and 2.4 times higher after a $0.1 \mu \mathrm{g} / \mathrm{kg}$ dose (Fig. 1c). Between days 7 and 35 the concentration of TCDD declined by $91-94 \%$ in liver, compared with only 50 $70 \%$ in pancreas (Fig. 1d). These data indicate that TCDD may be more stable in the pancreas than classical target tissues.

\section{CYP1A enzymes are not induced in immortalised beta or alpha cell lines}

To test our hypothesis that CYP1A enzymes are inducible in pancreatic endocrine cells, we first treated INS1 cells and HepG2 liver cells with CYP1A inducers TCDD and 3-MC. Both chemicals profoundly increased CYP1A1 and CYP1A2 enzyme activity in HepG2 cells (Fig. 2a, b), but not in INS1 cells (Fig. 2c, d). A modest but statistically significant $\sim 2.4-$ fold increase in Cyplal gene expression was detected in TCDD-exposed INS1 cells, but this was unremarkable compared with the 440 -fold increase in HepG2 cells (Fig. 2e). Moreover, changes in gene expression did not result in measureable increases in enzyme activity in INS1 cells or any other pancreatic endocrine cell lines tested (Fig. 2f).

\section{Functional CYP1A1 enzymes are strongly induced in human islets}

Since immortalised cell lines are not always an appropriate model, we next tested our hypothesis in primary human islets. Remarkably, both 3-MC and TCDD potently induced CYP1A1 expression in human islets $(\sim 100$-fold and $\sim 270$-fold, respectively; Fig. 3a), while CYP1A2 was only modestly induced $\sim 2.7$-fold by TCDD (Fig. 3b). Interestingly, glucose-induced C-peptide secretion was increased by $3-\mathrm{MC}$, but inhibited by TCDD (Fig. 3c). Neither gene nor protein expression of MafA, a critical beta cell transcription factor, was affected by chemical exposure (Fig. 3d, e).

In three additional organ donors, CYP1A1, but not CYP1A2, was significantly upregulated by $10 \mathrm{nmol} / 1 \mathrm{TCDD}$ (Fig. 3f). Importantly, this was associated with a significant increase in CYP1A1 enzyme activity (Fig. 3g), demonstrating that human islets harbour functional xenobiotic metabolism enzymes. In these donors, C-peptide secretion was not impacted by TCDD exposure (Fig. 3h). Islets appeared to be generally healthy, confirming that these doses of TCDD were not cytotoxic (Fig. 3i).

To determine whether other stressors induce CYP1A expression or interact with TCDD, human islets were cotreated with cytokines (to mimic inflammatory stress) or thapsigargin (to mimic endoplasmic reticulum stress). TCDD induced CYP1A1 26 -fold with or without thapsigargin (Fig. 4a). However, cotreatment with cytokines completely prevented CYP1A1 induction by TCDD (Fig. 4a). CYP1A2 gene expression was unchanged by any combination of stressors (Fig. 4b). TCDD significantly suppressed glucose-induced C-peptide secretion in two organ donors (Fig. 4c, d), and this effect was prevented by cotreatment with exendin-4 (Fig. 4d). Exposure to cytokines or thapsigargin also suppressed C-peptide secretion, irrespective of cotreatment with TCDD (Fig. 4c, d).

Given the variable insulin secretory responses from different organ donors (Figs. 3c, h, 4c, d), we compiled these results in Fig. 4e-g. Despite the biological variability in C-peptide production among donors, a consistent pattern of decreased C-peptide secretion was observed for each organ donor following TCDD treatment, particularly under HG conditions ( $p=0.063$; Fig. $4 \mathrm{f}$ ). The change in glucoseinduced C-peptide secretion by TCDD-treated (vs control) human islets ranged from $-3 \%$ to $-60 \%$ among the five donors (Fig. 4g). 

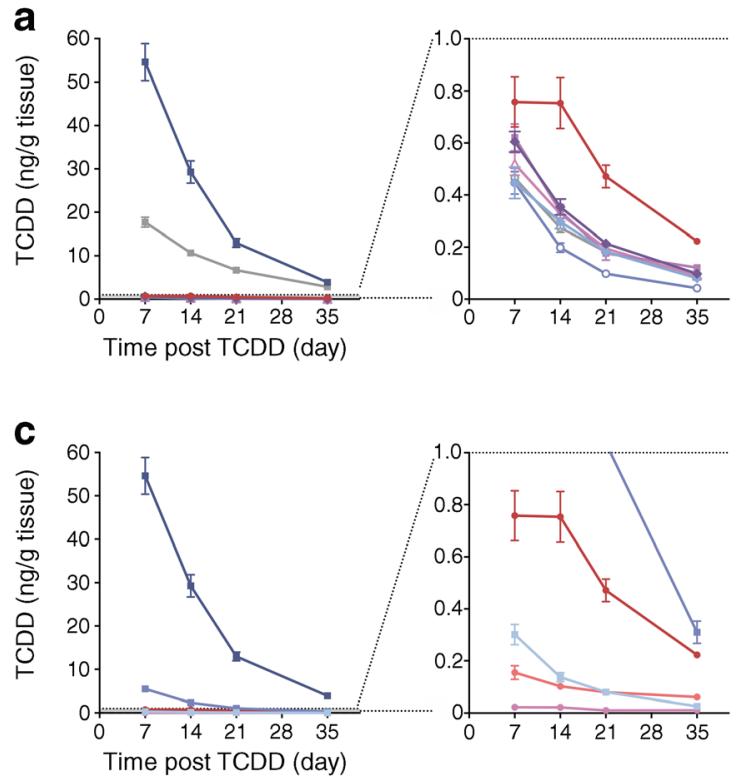

Fig. 1 TCDD levels are more stable in the pancreas than in other tissues. Data from a published biodistribution study [37] were re-analysed to compare TCDD levels in the pancreas with other mouse tissues at 7 , 14,21 and 35 days following oral administration of TCDD $(0.1,1.0$ or $10 \mu \mathrm{g} / \mathrm{kg}$ ) to female B6C3F1 mice ( $n=5$ mice per group). (a, b)

\section{TCDD causes long-term CYP1A1 induction in mouse islets in vivo}

Our next question was whether functional CYP1A enzymes could be induced in islets following systemic TCDD exposure in vivo rather than direct exposure ex vivo. Mice were injected with a single high dose of TCDD (20,100 or $200 \mu \mathrm{g} / \mathrm{kg}$ ) or corn b

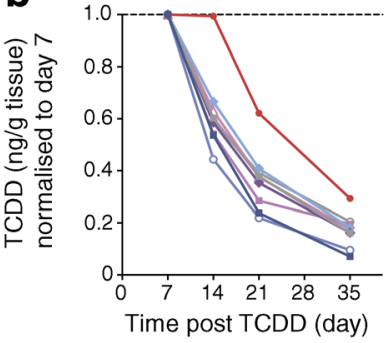

$\rightarrow$ Pancreas

- Liver

- Adipose tissue

$\rightarrow$ Spleen

$\rightarrow$ Kidney

$\rightarrow$ Brain

- Lung

$\triangle$ Thymus

- Mesenteric lymph nodes d

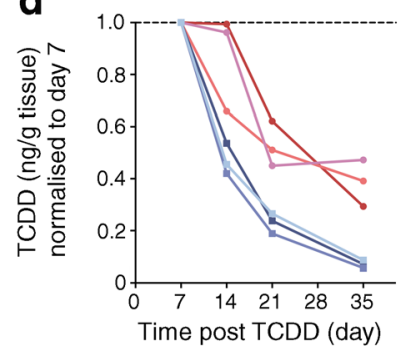

$-0.1 \mu \mathrm{g} / \mathrm{kg}$ TCDD, pancreas $\rightarrow 1.0 \mu \mathrm{g} / \mathrm{kg}$ TCDD, pancreas $\rightarrow 10 \mu \mathrm{g} / \mathrm{kg}$ TCDD, pancreas - $0.1 \mu \mathrm{g} / \mathrm{kg}$ TCDD, liver - $1.0 \mu \mathrm{g} / \mathrm{kg}$ TCDD, liver $-10 \mu \mathrm{g} / \mathrm{kg}$ TCDD, liver

Concentration of TCDD (ng/g tissue) in various tissues after administration of $10 \mu \mathrm{g} / \mathrm{kg}$ TCDD. (c, d) Concentration of TCDD (ng/g tissue) in liver and pancreas after oral administration of $0.1,1.0$ or $10 \mu \mathrm{g} / \mathrm{kg}$ TCDD. Data are presented as mean \pm SD $(\mathbf{a}, \mathbf{c})$ and mean TCDD concentration normalised to day $7(\mathbf{b}, \mathbf{d})$

oil, and tissues harvested $24 \mathrm{~h}$ later (Fig. 5a). As expected, Cyp1a1 and Cyp1a2 were induced $\sim 40$-fold and $\sim 10$-fold, respectively, in the liver following TCDD exposure (Fig. 5b, c). In islets, Cypla1 was induced $\sim 5$-fold by TCDD (all doses; Fig. 5d). Cypla 2 was only induced by $20 \mu \mathrm{g} / \mathrm{kg}$ TCDD (Fig. 5e). Most importantly, a dose-dependent increase in CYP1A1

a
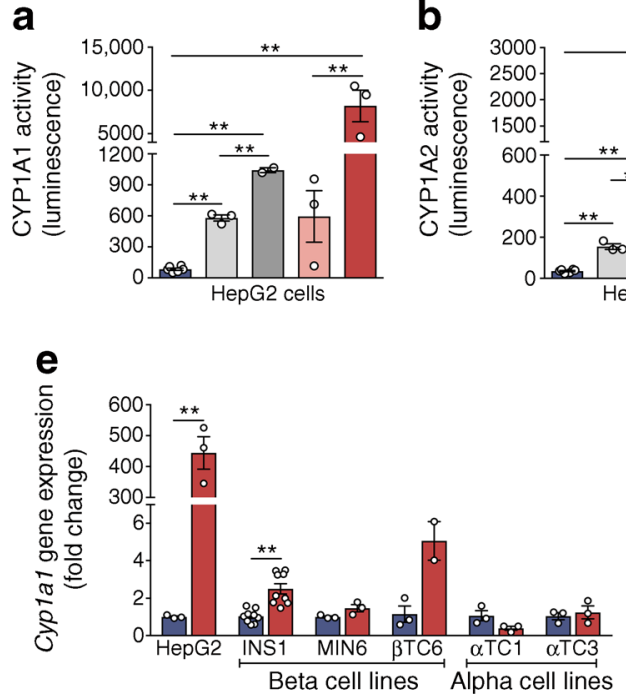

Fig. 2 Xenobiotics do not induce CYP1A enzymes in immortalised pancreatic endocrine cell lines. Liver cells (HepG2), beta cell lines (INS1, MIN6, $\beta$ TC6) and alpha cell lines ( $\alpha \mathrm{TC} 1$ and $\alpha \mathrm{TC} 3)$ were treated for $48 \mathrm{~h}$ with media containing vehicle (control), 3-MC $(0.1$ or $1.0 \mu \mathrm{mol} /$ 1) or TCDD (1.0 or $10 \mathrm{nmol} / \mathrm{l})$. (a-d) Following treatment, CYP1A1 and CYP1A2 enzyme activity was measured in $\mathrm{HepG} 2(\mathbf{a}, \mathbf{b})$ and INS1 cells
C

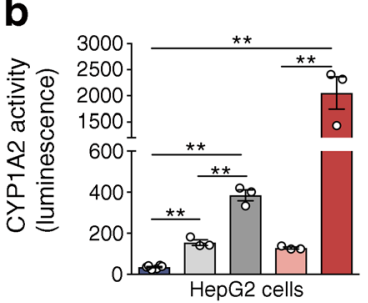

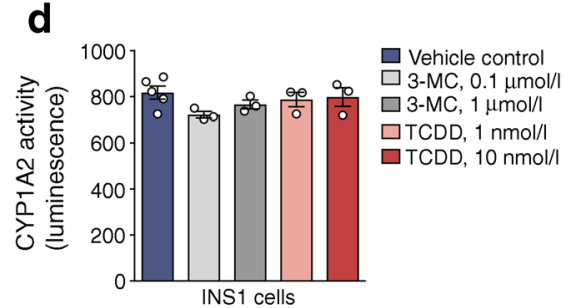

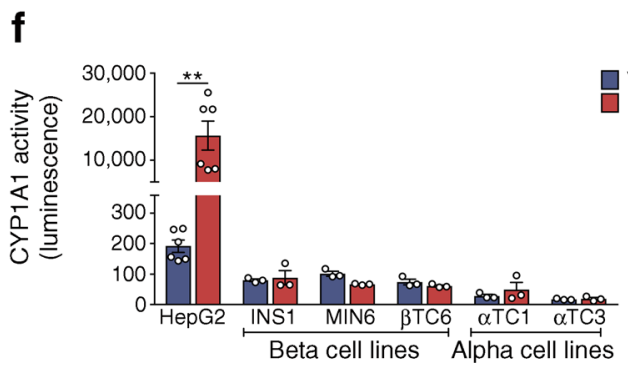

Vehicle control

TCDD, $10 \mathrm{nmol} / /$

(c, d). $* * p<0.01$, one-way ANOVA with Tukey's post hoc test. (e) Cyp 1al gene expression and (f) CYP1A1 enzyme activity were measured after exposure to vehicle (DMSO) or $10 \mathrm{nmol} / 1 \mathrm{TCDD}$ in all immortalised cell lines. ${ }^{* *} p<0.01$, unpaired two-tailed $t$ test. All data are presented as mean \pm SEM and individual data points represent technical replicates of cells treated independently in different wells 

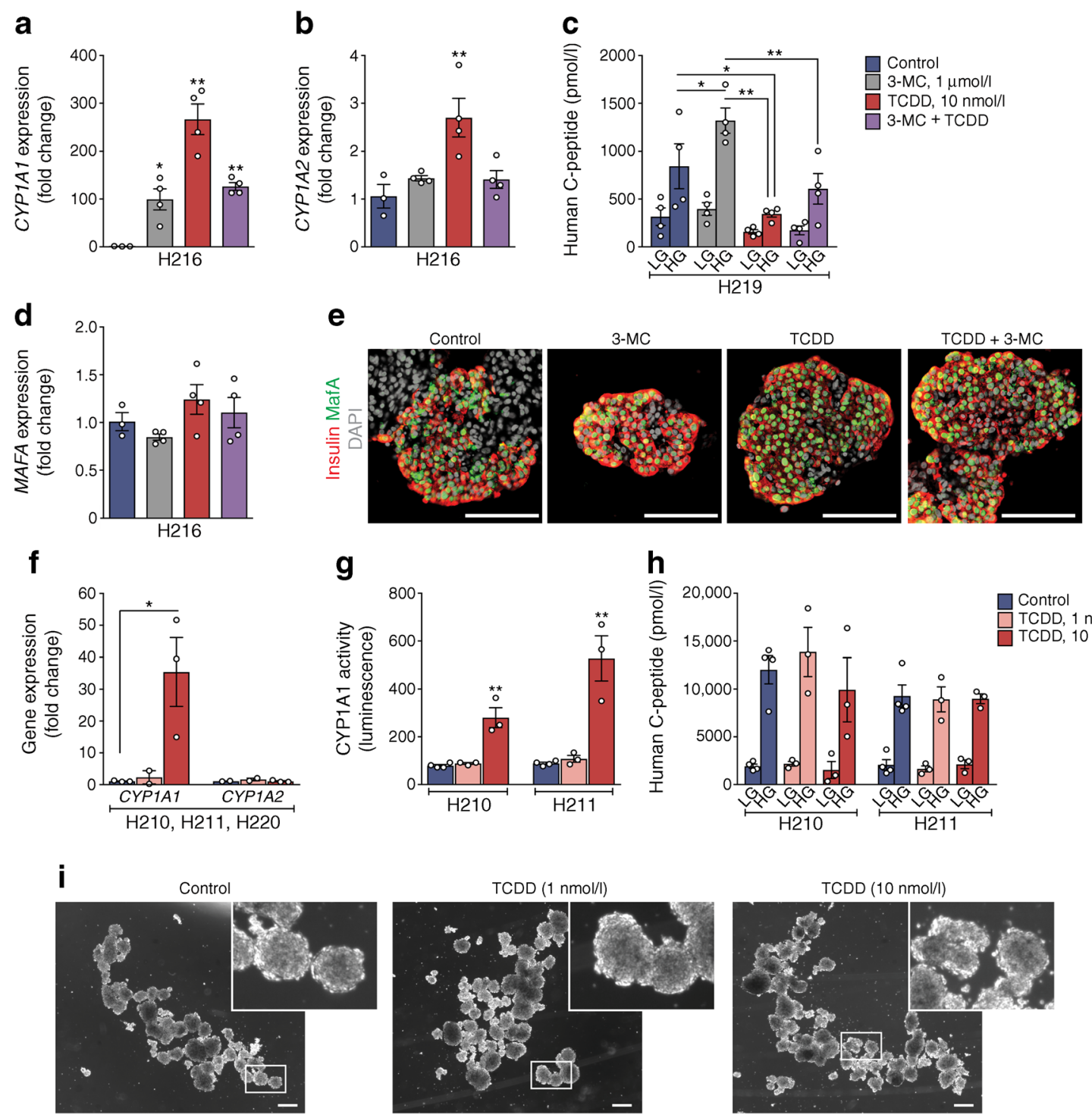

Fig. 3 Functional CYP1A1 enzymes are induced in human islets following xenobiotic exposure in vitro. Human islets were treated with vehicle, or $3-\mathrm{MC}(1 \mu \mathrm{mol} / \mathrm{l}) \pm \mathrm{TCDD}(1$ or $10 \mathrm{nmol} / \mathrm{l})$, for $48 \mathrm{~h}$ in vitro. $(\mathbf{a}, \mathbf{b}, \mathbf{d})$ Gene expression of CYP1A1, CYP1A2 and MAFA, expressed as the fold change relative to control. ${ }^{*} p<0.05, * * p<0.01$ vs control (one-way ANOVA with Dunnet's post hoc test). (c) Human C-peptide secretion after $1 \mathrm{~h}$ in LG $(2.9 \mathrm{mmol} / \mathrm{l})$ and HG $(16.7 \mathrm{mmol} / \mathrm{l})$ buffer. $* p<0.05$, $* * p<0.01$ (two-way repeated measures ANOVA with Tukey's post hoc test). (e) Representative images of human islets with immunofluorescence staining for insulin (red), MafA (green) and DAPI (grey). Scale bars represent $100 \mu \mathrm{m}$. (f) Gene expression of CYP1A1 and CYP1A2,

enzyme activity (but not CYP1A2) was detected in islets $24 \mathrm{~h}$ post TCDD (Fig. 5f, g).

To assess the longevity of CYP1A1 activation, we followed a second cohort of mice for 2 weeks after a high-dose TCDD injection $(200 \mu \mathrm{g} / \mathrm{kg}$; Fig. 5h). Cyplal was induced $\sim 12$-fold in TCDD-exposed liver at 1 and 2 weeks post injection (Fig. 5i), compared with the $\sim 35$-fold increase after $24 \mathrm{~h}$ (Fig. 5b). In islets, Cyplal was elevated $\sim 4$-fold at 1 week post TCDD, but unchanged at 2 weeks (Fig. 5j). However,

expressed as fold change relative to control. $* p<0.05$ vs control (oneway ANOVA with Dunnet's post hoc test). (g) CYP1A1 enzyme activity. $* * p<0.01$ vs control (one-way ANOVA with Dunnet's post hoc test). (h) Human C-peptide secretion after $1 \mathrm{~h}$ in LG and HG buffer. (i) Representative brightfield images showing gross morphology of human islets after $48 \mathrm{~h}$ in vitro treatments. Scale bars represent 100 pixels. All data are presented as mean \pm SEM. Individual data points represent technical replicates from a single organ donor $(\mathbf{a}, \mathbf{b}, \mathbf{d}: \mathrm{H} 216 ; \mathbf{c}: \mathrm{H} 219 ; \mathbf{g}, \mathbf{h}$ : $\mathrm{H} 210, \mathrm{H} 211$ ), except for (f) where data points represent biological replicates from three organ donors (H210, H211, H220)

while Cyplal gene levels were declining in islets, CYP1A1 enzyme activity increased dramatically (Fig. 5k). Whereas only a 1.9-fold increase in CYP1A1 activity was detected in TCDD-exposed islets at $24 \mathrm{~h}$ (Fig. 5f), CYP1A1 activity increased $\sim 40$-fold and $\sim 80$-fold in islets at 1 and 2 weeks, respectively, after the single TCDD injection (Fig. 5k). Islet CYP1A2 activity was unchanged (Fig. 5l).

We performed immunofluorescence staining on pancreas sections from TCDD-injected mice to localise CYP1A1 

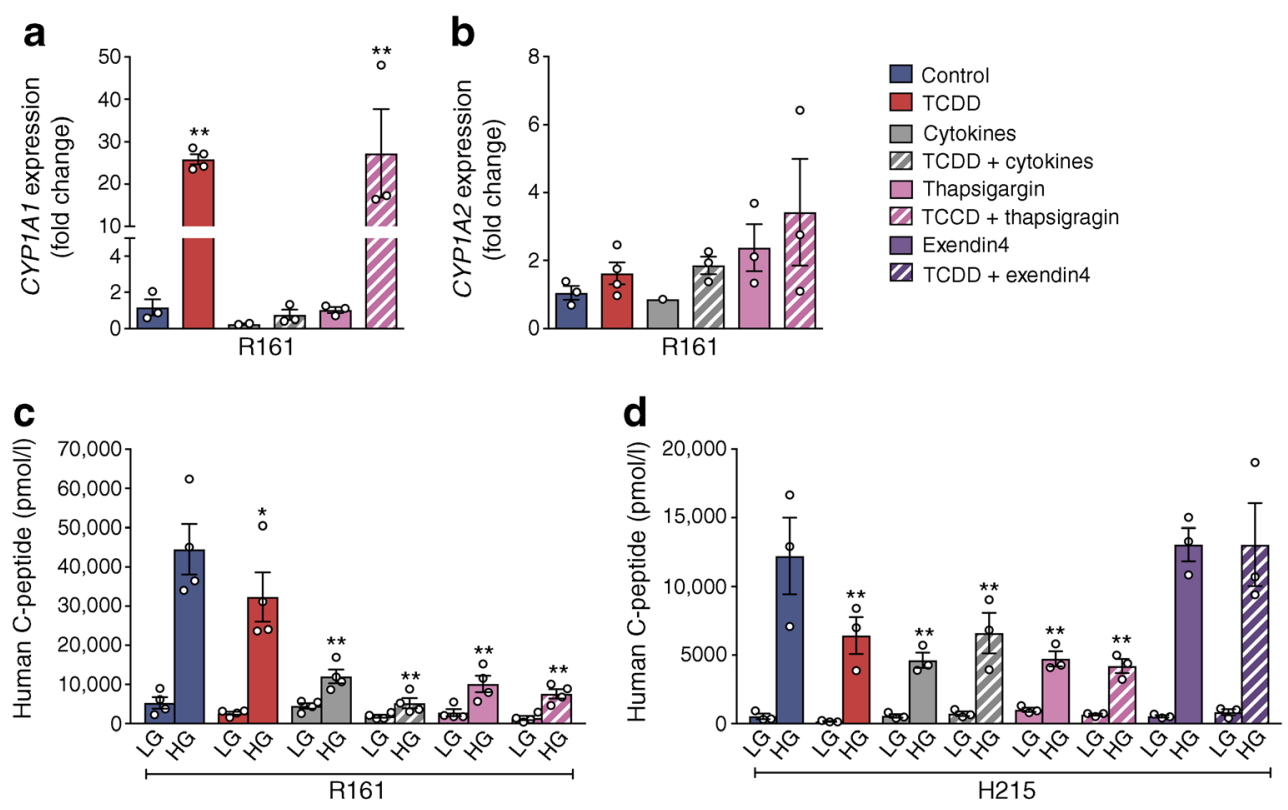
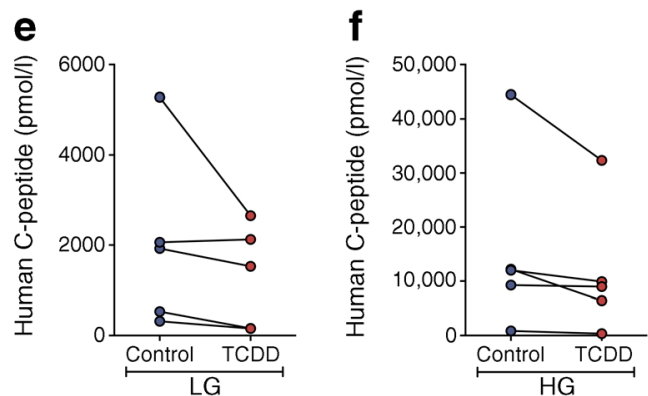

Fig. 4 Cotreatment with cytokines, but not thapsigargin, interferes with CYP1A1 induction in human islets. Human islets were treated with media containing DMSO (control), $10 \mathrm{nmol} / \mathrm{l} \mathrm{TCDD}$ alone, cytokines (1000 U/ $\mathrm{ml} \mathrm{IFN} \gamma, 50 \mathrm{ng} / \mathrm{ml}$ TNF- $\alpha, 10 \mathrm{ng} / \mathrm{ml} \mathrm{IL} 1 \beta) \pm 10 \mathrm{nmol} / 1 \mathrm{TCDD}, 1 \mu \mathrm{mol} / 1$ thapsigargin $\pm 10 \mathrm{nmol} / 1 \mathrm{TCDD}$, or $10 \mathrm{nmol} / 1$ exendin- $4 \pm 10 \mathrm{nmol} / 1$ TCDD for $48 \mathrm{~h}$ in vitro. (a, b) Gene expression of CYP1A1 (a) and CYP1A2 (b), expressed as fold change relative to control. $* * p<0.01$ vs control (one-way ANOVA with Dunnet's post hoc test). (c, d) Human Cpeptide after a $1 \mathrm{~h}$ incubation in LG $(2.9 \mathrm{mmol} / \mathrm{l})$ and $\mathrm{HG}(16.7 \mathrm{mmol} / \mathrm{l})$ buffer. $* p<0.05, * * p<0.01$ vs control (two-way repeated measures ANOVA with Dunnet's post hoc test). (e-g) Compiled human C-peptide

expression within islets, but unfortunately the CYP1A1 antibodies we tested were unreliable (ESM Table 1). Immunofluorescence was either undetectable in TCDD-exposed liver and pancreas or the same pattern of immunoreactivity was observed in both wildtype (WT) and Cypla1/1a2 knockout (KO) mice, indicating nonspecific immunoreactivity (representative examples shown in ESM Fig. 1). Therefore, we can conclude that CYP1A1 is upregulated in whole islets, but cannot comment on whether it is induced in beta cells specifically.

Finally, we investigated whether a more physiologically relevant TCDD dosing protocol would induce CYP1A1 enzymes in islets. Mice were injected two times per week with $20 \mathrm{ng} / \mathrm{kg}$ TCDD (Fig. $5 \mathrm{~m}$ ), which is 10,000 times lower than the single high-dose model (Fig. 5a-1). After 2 weeks Cyplal levels were upregulated $\sim 40$-fold in liver (Fig. 5n) and $~ 8$-fold in islets (Fig. 5o). This was comparable

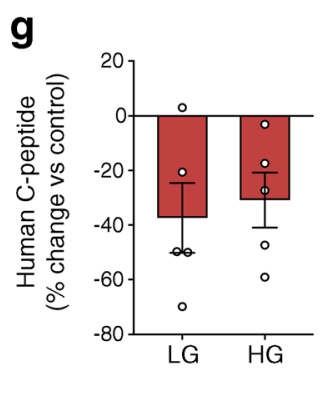

secretion data from five different organ donors, expressed as the mean human C-peptide concentration following LG (e) and HG (f) conditions, as well as the percentage change for TCDD-exposed islets relative to their respective control islets (g). A Wilcoxon matched-pairs signed rank test was performed to compare human C-peptide secretion for each organ donor with and without TCDD exposure (LG: $p=0.125$, HG: $p=$ $0.063)$. All data are presented as mean \pm SEM. Individual data points represent technical replicates from a single organ donor $(\mathbf{a}-\mathbf{c}$ : R161; d: H215), except for $(\mathbf{e}-\mathbf{g})$ where data points represent biological replicates from five different organ donors (H210, H211, H215, H219 and R161)

to the degree of Cyplal induction $24 \mathrm{~h}$ after a single high-dose TCDD injection (Fig. 5b, d). Cyplal levels did not change in TCDD-exposed pancreatic exocrine tissue (Fig. 5p).

\section{TCDD exposure suppressed glucose-stimulated insulin secretion}

Activation of CYP1A1 enzymes in islets strongly suggests that islets are directly exposed to TCDD in vivo. Therefore, we investigated the impact of TCDD on beta cell function and survival rate. We first characterised the mice exposed to a single high dose of TCDD (Fig. 6a) in which islet CYP1A1 enzyme activity was dramatically upregulated at 1 and 2 weeks (Fig. 5k). These mice can only be maintained for $\sim 2$ weeks, as their health begins to decline thereafter [47]. Beginning at 
a

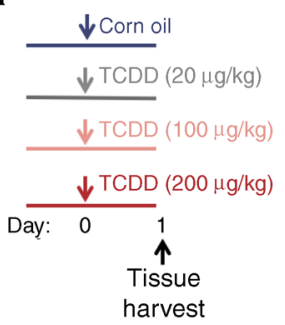

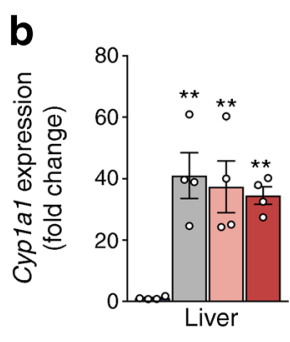

C

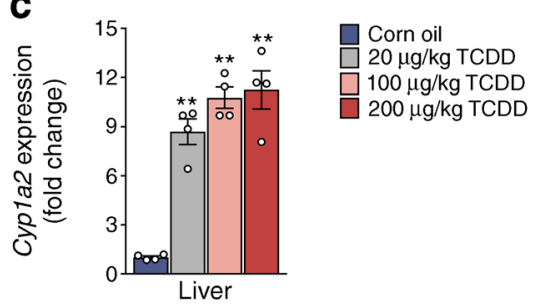

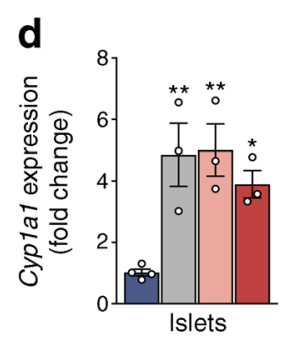
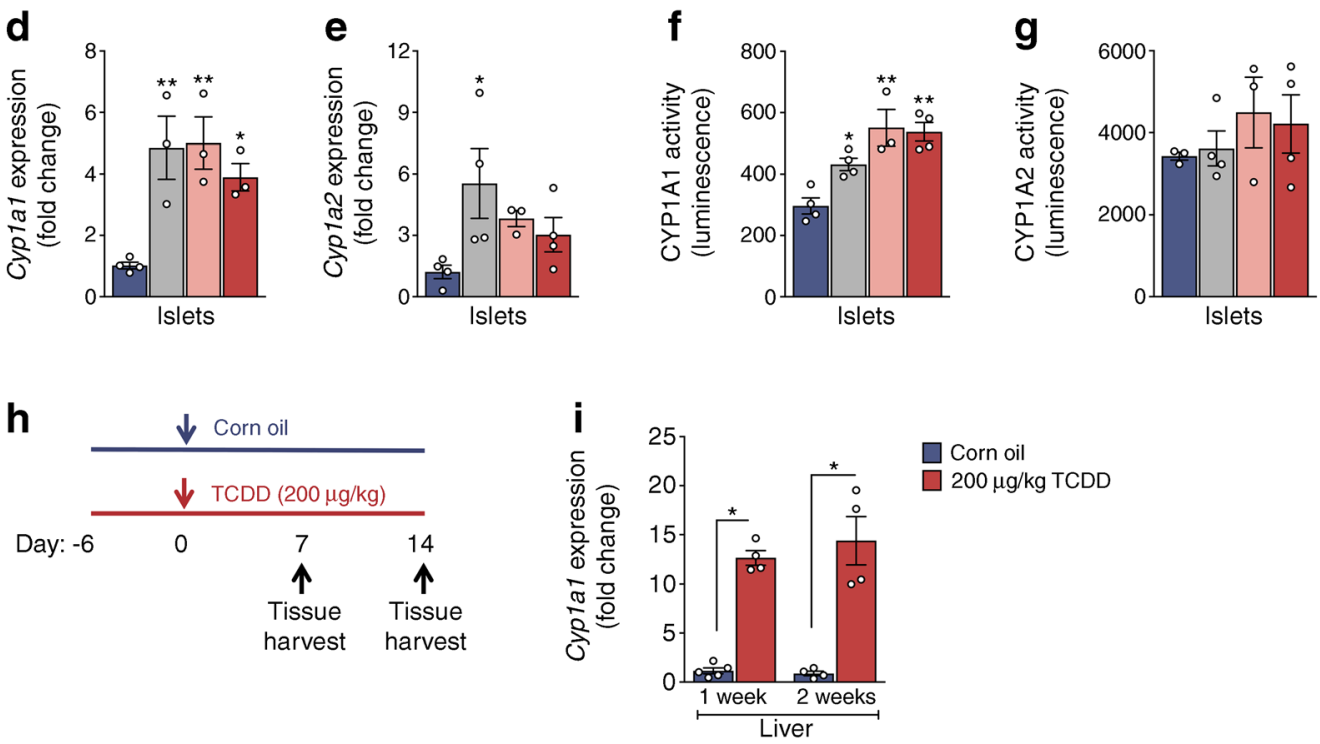

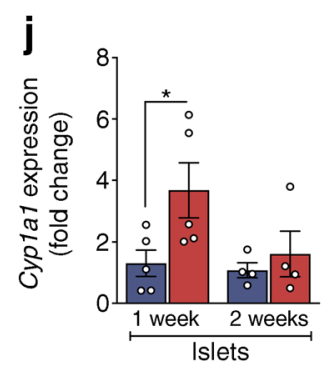

m

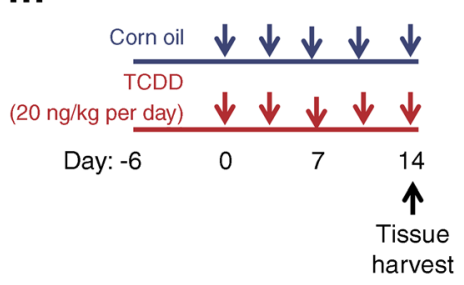

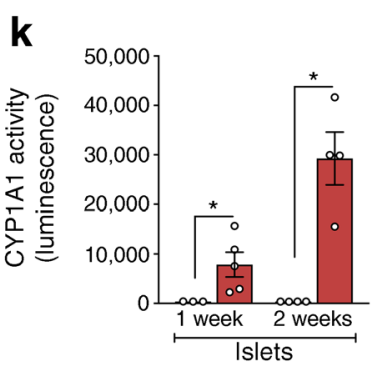

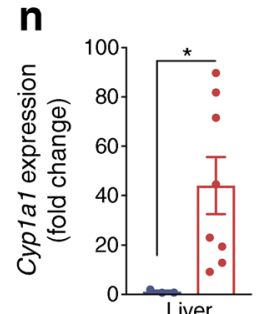

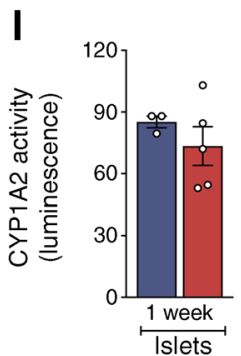
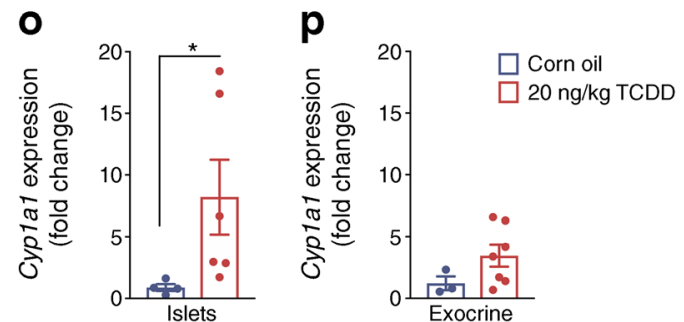

6 days post TCDD, we observed modest but significant body weight loss ( $\sim 5 \%$; Fig. $6 \mathrm{~b})$ and a drastic decline in fasting blood glucose levels (Fig. 6c). However, on day 5 TCDDexposed mice had slightly higher blood glucose levels 15 min after a glucose challenge with no overall change in glucose tolerance (Fig. 6d). By day 12, TCDD-exposed mice were profoundly hypoglycaemic during the GTT (Fig. 6e).
Plasma insulin levels were signficantly lower in TCDDexposed mice during the GTT on both days (Fig. 6f, g).

In contrast to the single high-dose TCDD, glucose homeostasis was largely unaffected by multiple low-dose TCDD exposures for 25 days (ESM Fig. 2). Fasting glucose levels were modestly decreased in TCDD-exposed mice (ESM Fig. 2c), but there was no difference in glucose tolerance (ESM Fig. 2e), body weight (ESM Fig. 2b), insulin sensitivity (ESM 
Fig. 5 CYP1A1 gene expression and enzyme activity are induced in mouse islets in vivo. (a-g) Male C57B1/6 mice were injected i.p. with either corn oil (vehicle) or TCDD (20 $\mu \mathrm{g} / \mathrm{kg}, 100 \mu \mathrm{g} / \mathrm{kg}$ or $200 \mu \mathrm{g} / \mathrm{kg}$ ) and euthanised $24 \mathrm{~h}$ later to harvest liver and isolate islets (schematic timeline shown in [a]). (b, d) Cypla1 and (c, e) Cypla2 gene expression expressed as fold change relative to controls in liver (b, c) and isolated islets $(\mathbf{d}, \mathbf{e})$. (f) CYP1A1 and (g) CYP1A2 enzyme activity was measured in islets at $24 \mathrm{~h}$. (h-l) Male C57Bl $/ 6$ mice were injected i.p. with either corn oil or TCDD $(200 \mu \mathrm{g} / \mathrm{kg})$ and euthanised either 7 or 14 days later (schematic timeline shown in [h]). (i, j) Cyp lal gene expression was measured in liver (i) and isolated islets (j) at 1 and 2 weeks post injection (expressed as fold change relative to control). (k) CYP1A1 and (I) CYP1A2 enzyme activity in isolated islets at 1 and 2 weeks post injection. $(\mathbf{m}-\mathbf{p})$ Male C57B1/6 mice were injected i.p. with either corn oil or TCDD ( $20 \mathrm{ng} / \mathrm{kg}$ per day) twice per week and euthanised 14 days later (schematic timeline shown in $[\mathbf{m}])$. (n-p) Cyplal gene expression was measured in liver (n), isolated islets (o) and pancreatic exocrine tissue (p) on day 14 (expressed as fold change relative to control). All data are presented as mean \pm SEM. Individual data points represent biological replicates from different mice. (b-g) $* p<0.05, * * p<0.01$ vs control, two-way repeated measures ANOVA with Dunnet's post hoc test. $(\mathbf{i}-\mathbf{l}, \mathbf{n}-\mathbf{p}) * p<0.05$, $* * p<0.01$ vs control, unpaired two-tailed $t$ test
Fig. 2d) or plasma insulin levels during the GTT (ESM Fig. $2 \mathrm{f})$.

To better understand whether the low plasma insulin levels following high-dose TCDD (Fig. 6f, g) were caused by impaired beta cell function vs adaptation to other effects of TCDD (e.g. hepatic toxicity, increased insulin clearance), islets were isolated on day 7. Interestingly, glucose-stimulated insulin secretion was suppressed in islets from TCDD-injected mice compared with controls ex vivo (Fig. 6h). Next, islets were isolated from Cyp1a1/Cypla2 KO or WT mice and treated with TCDD ex vivo to determine whether induction of CYP1A1 in islets might be involved in suppressing insulin secretion. As expected, Cypla1 was induced by TCDD in WT islets and non-detectable in KO islets, irrespective of treatment (Fig. 7a). Consistent with our findings in vivo (Fig. 6) and in human islets (Figs. 3c, 4c-g), TCDD suppressed glucose-stimulated insulin secretion in WT islets (Fig. 7b). In contrast, TCDD did not suppress insulin secretion in Cypla1/1a2 KO islets, although control $\mathrm{KO}$ islets had a

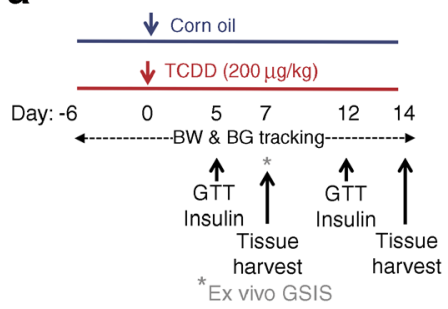

b

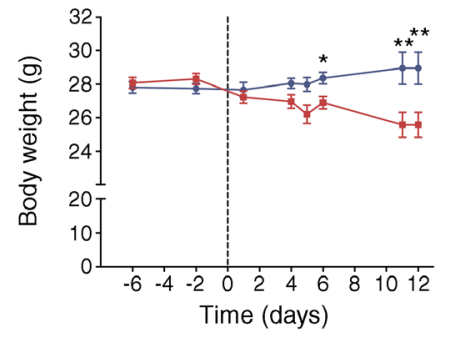

C

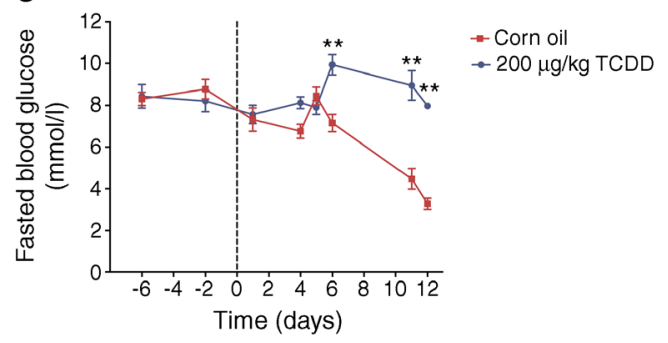

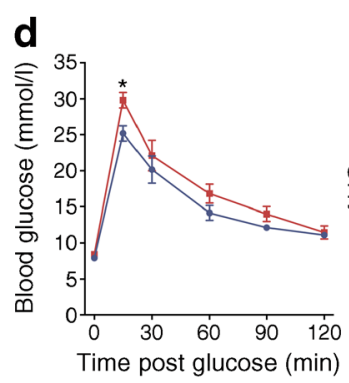

f

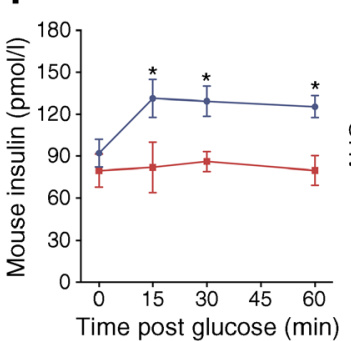

e

Corn oil

$200 \mu \mathrm{g} / \mathrm{kg}$ TCDD
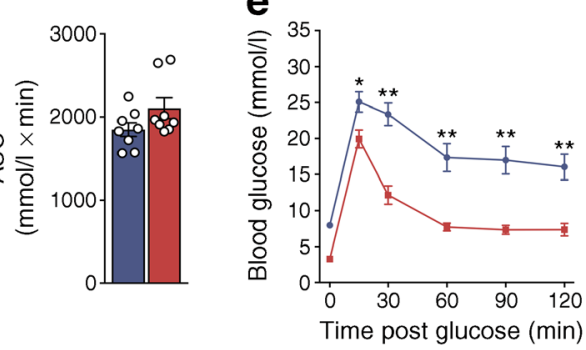

Time post glucose (min)

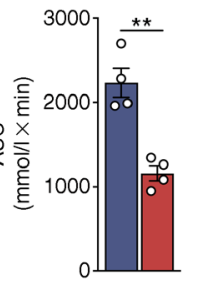

h

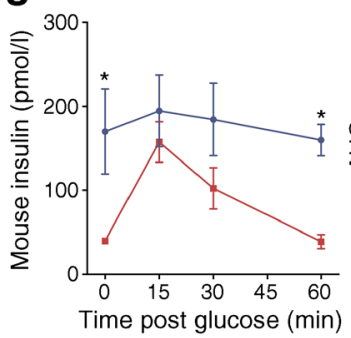

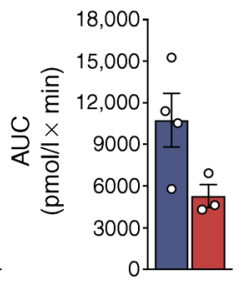

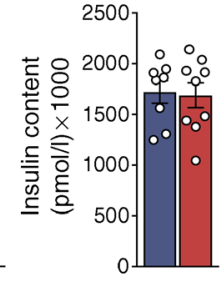

Fig. 6 A single high-dose TCDD injection leads to suppressed plasma insulin levels in vivo. Male C57Bl/6 mice were injected i.p. with either corn oil (vehicle) or TCDD $(200 \mu \mathrm{g} / \mathrm{kg})$ and euthanised either 7 or 14 days later (schematic timeline shown in [a]). BG, blood glucose; BW, body weight. (b) Body weight and (c) blood glucose were measured after a $4 \mathrm{~h}$ morning fast throughout the study. (d, e) Blood glucose and (f, g) plasma insulin were measured during a GTT on days $5(\mathbf{d}, \mathbf{f})$ and $12(\mathbf{e}, \mathbf{g})$. (h) On day 7 islets were isolated and glucose-stimulated insulin secretion (GSIS) was measured ex vivo after $1 \mathrm{~h}$ in $\mathrm{LG}(2.9 \mathrm{mmol} / \mathrm{l})$ and $1 \mathrm{~h}$ in $\mathrm{HG}$ ( $16.7 \mathrm{mmol} / \mathrm{l})$, followed by total insulin content measurement. All data are presented as mean \pm SEM. Individual data points represent biological replicates from different mice. ${ }^{*} p<0.05, * * p<0.01$ vs control; (b, c) two-way ANOVA with Šídák multiple comparisons test, $(\mathbf{d}-\mathbf{h})$ two-way repeated measures ANOVA with Šídák multiple comparisons test, $(\mathbf{d}-\mathbf{g})$ unpaired two-tailed $t$ test for AUC 

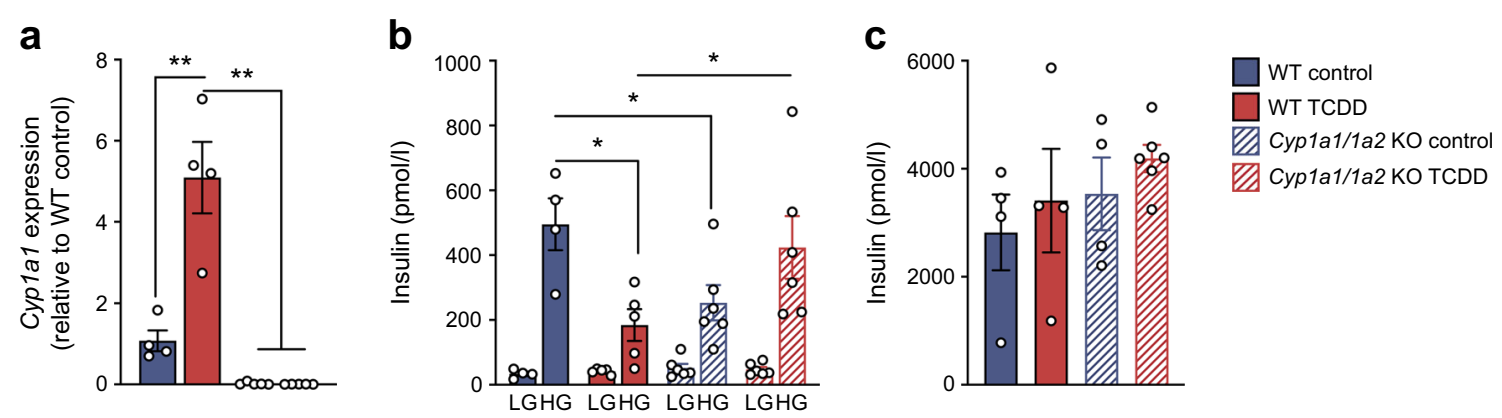

Fig. 7 TCDD suppressed glucose-stimulated insulin secretion in male WT islets but not Cypla1/1a2 $\mathrm{KO}$ islets. Islets were isolated from male WT mice and mice with a global KO of Cypla1 and Cypla2 (Cyplall $1 a 2 \mathrm{KO}$ ) and treated ex vivo for $48 \mathrm{~h}$ with $10 \mathrm{nmol} / 1 \mathrm{TCDD}$. (a) Cyplal gene expression was expressed relative to WT control levels. (b) Insulin secretion was measured ex vivo after $1 \mathrm{~h}$ in LG $(2.9 \mathrm{mmol} / \mathrm{l})$ and $1 \mathrm{~h}$ in

unexpectedly lower insulin secretion than WT islets (Fig. 7b), suggesting a role for basal CYP1A1/CYP1A2 in regulating beta cell function. Total insulin content was not affected by genotype or TCDD (Fig. 7c).

\section{TCDD causes beta cell death and suppression of anti-apoptotic genes in islets}

Reduced plasma insulin can also be caused by beta cell loss, so we next assessed pancreas histology. Surprisingly, pancreas morphology appeared relatively normal by H\&E staining, unlike the liver, which showed obvious signs of inflammation and cell damage (ESM Fig. 3). Likewise, there was no change in endocrine cell composition within islets (percentage insu$\operatorname{lin}^{+}$, glucagon ${ }^{+}$and somatostatin ${ }^{+}$area) at 7 days post TCDD (Fig. 8a, b). There was, however, a remarkably high percentage of TUNEL ${ }^{+}$islet cells, nearly all of which were insulin ${ }^{+}$rather than insulin ${ }^{-}$(Fig. 8c, e). On average, $\sim 13 \%$ of insulin ${ }^{+}$cells were TUNEL $^{+}$(Fig. 8c, e), compared with only $\sim 1 \%$ TUNEL $^{+}$ liver cells in the same mice (Fig. 8c, d). At both 7 and 14 days post TCDD, the liver had significant induction of proinflammatory cytokines (Tnfa, Il-1b), as well as inhibitors of apoptosis Birc3 and Xiap (Fig. 8f, g). In stark constrast, TCDD significantly suppressed Birc3 expression in islets on days 7 and 14 (Fig. 8h, i), as well as $I l-1 b$ and $N f-k b$ on day 14 (Fig. 8i).

\section{Discussion}

Our study demonstrates that xenobiotic metabolising CYP enzymes are activated within pancreatic islets following pollutant exposure. Specifically, CYP1A1 gene expression and enzyme activity were induced in human and mouse islets following direct TCDD exposure in vitro, and in mouse islets following systemic TCDD exposure in vivo. The enzyme activity assay measures CYP1A1-mediated metabolism of a proluciferin substrate into D-
HG (16.7 mmol/l), followed by (c) total insulin content in islets. All data are presented as mean \pm SEM. Individual data points represent biological replicates from different mice. $* p<0.05, * * p<0.01$; (a) one-way ANOVA with Tukey's multiple comparisons test, (b) two-way repeated measures ANOVA with Tukey's multiple comparisons test

luciferin, indicating that the upregulated $C Y P 1 A 1$ gene is indeed translated into functional enzymes capable of producing metabolites. To our knowledge, this is the first evidence of functional CYP enzymes in the endocrine pancreas. Remarkably, the activity level of CYP1A1 enzymes in islets increased for at least 2 weeks after a single high-dose TCDD injection, even though Cyplal gene expression in islets had returned to baseline. Moreover, this pathway was activated in islets by both a supraphysiological dose of TCDD in vivo and a biologically relevant, multiple low-dose exposure protocol.

These findings have several important implications. First and foremost, local activation of CYP1A1 in islets provides strong evidence that environmental pollutants reach pancreatic endocrine cells in vivo at sufficient levels to directly alter cell signalling. Given the highly specialised nature of endocrine cells, the signalling pathways activated by dioxin in islets will likely differ from classical target tissues. This was apparent in our analysis of

Fig. 8 TCDD causes beta cell death in vivo. Male C57Bl/6 mice were injected i.p. with either corn oil (vehicle) or TCDD $(200 \mu \mathrm{g} / \mathrm{kg})$ and euthanised either 7 or 14 days later. (a) The percentage of total islet area that was immunoreactive for insulin $\left(\mathrm{Ins}^{+}\right)$, glucagon $\left(\mathrm{Gcg}^{+}\right)$and somatostatin $\left(\mathrm{Sst}^{+}\right)$was quantified in pancreas sections collected at 7 days post injection. (b) Representative images of islets with insulin (red) and glucagon (green) immunoreactivity are shown. Scale bars represent $100 \mu \mathrm{m}$. (c) The percentages of liver cells and islet cells that coexpressed TUNEL were quantified in tissue sections at 1 week post injection. Within islets, $\mathrm{TUNEL}^{+}$cells were further delineated into insulin $^{+}$and insulin ${ }^{-}$cells. (d, e) Representative images of liver (d) and pancreas (e) showing TUNEL (green), insulin (red) and DAPI (blue) as individual channels and overlay images. Inset regions within the white boxes (labelled r1 and r2) are shown magnified below. Scale bars represent $50 \mu \mathrm{m}$, except for inset regions, which are $5 \mu \mathrm{m}$. Images from liver sections treated with DNase as a postive control are also provided (d). Arrows in (e) indicate TUNEL ${ }^{+}$cells. (f-i) Expression of genes involved in inflammation and apoptosis was measured in liver $(\mathbf{f}, \mathbf{g})$ and isolated islets $(\mathbf{h}, \mathbf{i})$ on day $7(\mathbf{f}, \mathbf{h})$ and day $14(\mathbf{g}, \mathbf{i})$. Gene levels are expressed as fold change relative to control. All data are presented as mean \pm SEM and individual data points represent biological replicates from different mice. $* p<0.05, * * p<0.01$ vs control, unpaired two-tailed $t$ test 

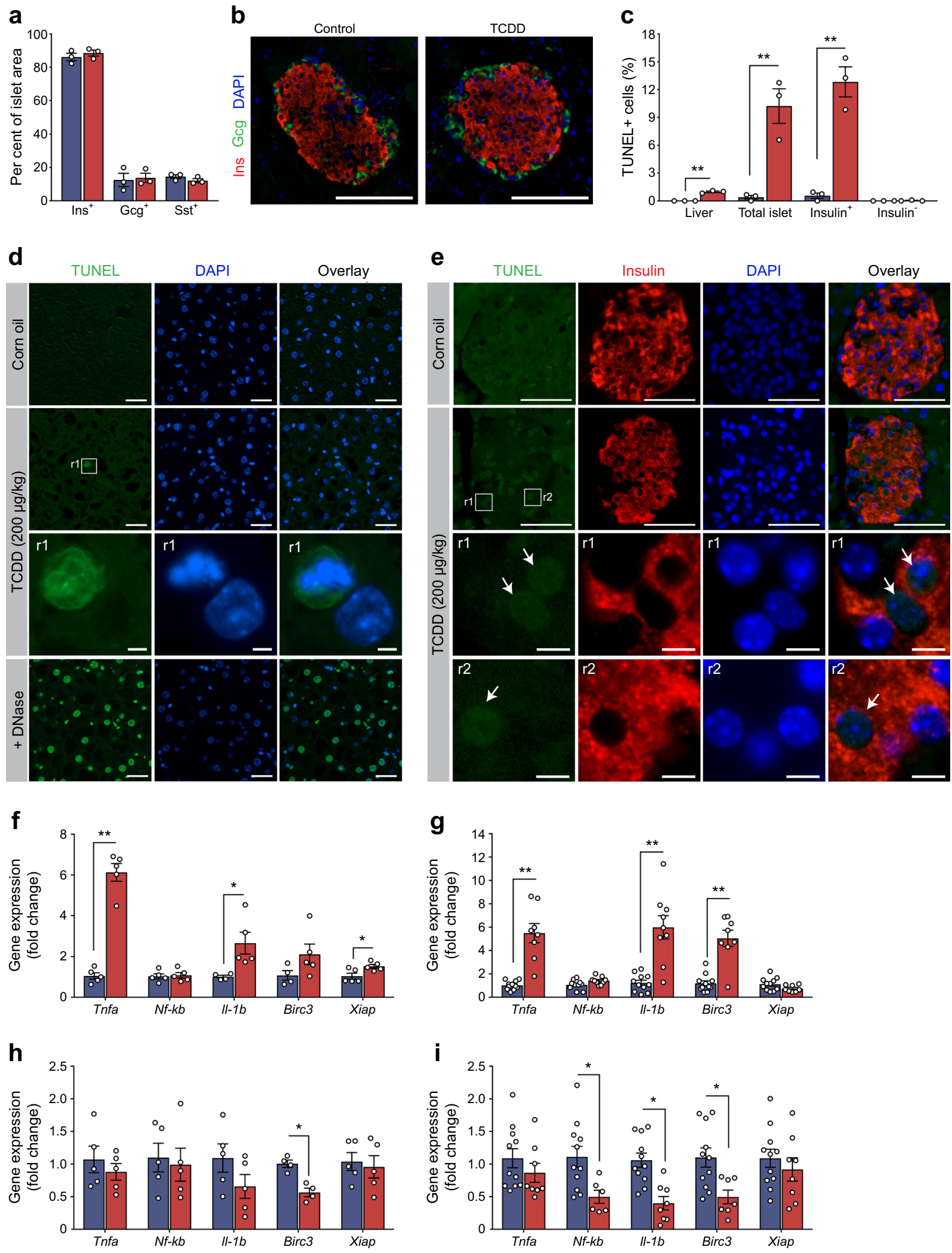

inflammatory signalling pathways in liver vs islets from TCDDexposed mice. In liver, TCDD profoundly upregulated proinflammatory cytokines, along with anti-apoptotic genes Birc3 and Xiap, likely as a protective response. However, TCDD significantly downregulated Birc3, an inhibitor of beta cell apoptosis [48], at 1 and 2 weeks in islets and did not induce 
cytokines. Birc3 activates $N f-k b$ [48], so the subsequent decrease in $N f-k b$ and $l l-l b$ at 2 weeks is consistent with TCDD suppressing Birc3 in islets. Nf- $\mathrm{kb}$ is also reportedly anti-apoptotic in beta cells [49], whereas Il-1b can be either pro-apoptotic or protective depending on timing and concentration [50-52]. The absence of an inflammatory and anti-apoptotic response in islets was associated with a dramatic increase in beta cell apoptosis, compared with only a modest increase in liver cell death in TCDD-exposed mice. Although a detailed mechanism remains to be elucidated, our data show that while TCDD induces CYP1A1 in liver and islets, the consequences of chemical exposure are profoundly different at both molecular and cellular levels.

Our study also shows that a single transient chemical exposure results in long-term activation of CYP1A1 enzymes within islets. The relatively slow decline of TCDD levels in pancreas [37], combined with the long-term induction of CYP1A1 activity in islets, suggests that pancreatic cells could be a 'sink' for long-term storage of lipophilic chemicals. Furthermore, the induction of Cyplal in islets, but not exocrine tissue, suggests that whole pancreas measurements of TCDD may underestimate islet exposure. We speculate that the dense intra-islet vascular network, designed to ensure rapid delivery of oxygen and nutrients to endocrine cells, also promotes delivery of xenobiotics to islets. Furthermore, the degree of CYP1A1 activation in islets was surprisingly high $(\sim 5-8$-fold lower than liver) considering the relatively small proportion of TCDD that reaches the pancreas. This supports both our hypothesis that islets are exposed to disproportionately high levels of TCDD and conclusions by Diliberto and colleagues [37] that some tissues require lower levels of TCDD to ellicit a response. Whether islets are exposed to more TCDD than predicted by biodistribution studies, or are highly sensitive to TCDD, our data conclusively show that CYP1A1 enzymes are activated locally following environmental chemical exposure.

Neither thapsigargin nor cytokines activated AhR signalling in human islets, but TCDD was surprisingly unable to induce CYP1A1 in the presence of proinflammatory cytokines. This could have important implications for how individuals with islet inflammation, including those with type 2 diabetes [53-56], respond to environmental chemicals that activate AhR signalling. For instance, if activation of CYP1A1 in islets is an important defence pathway, then islets with increased inflammation may be more sensitive to injury caused by environmental chemicals. On the other hand, if upregulation of CYP1A1 in islets is detrimental (for example, due to the formation of reactive metabolites), then islets in a proinflammatory state might be somewhat protected from the toxic effects of TCDD or other AhR ligands. Indeed, our data suggest that CYP1A enzymes may play a non-conventional role in islets. Direct TCDD exposure suppressed glucosestimulated insulin secretion in WT mouse islets, but not in Cypla1/1a2 KO islets, suggesting that CYP1A1 induction might inhibit insulin secretion. However, Cypla1/1a2 KO control islets also showed an unexpected decrease in insulin secretion compared with WT controls, pointing to a possible role for basal CYP1A1 in regulating beta cell function. More research is required to understand the role of CYP1A1 enzymes in islet physiology and possible interactions with proinflammatory cytokines.

The single high dose of TCDD used in these studies $(200 \mu \mathrm{g} / \mathrm{kg})$ was selected to study CYP1A1 activation in islets and was not ideal for assessing the impact of TCDD on beta cell function. After 1 week, TCDD-exposed mice displayed weight loss and hypoglycaemia, likely resulting from hepatotoxicity. This is consistent with previous reports $[47,57,58]$ and confounds our interpretation of potential direct effects of TCDD on islets. However, on day 5 , when blood glucose levels were still within a healthy range, TCDD-exposed mice displayed reduced plasma insulin levels during a GTT. Suppressed insulin secretion was also detected in isolated islets ex vivo on day 7 post TCDD, which is consistent with previous findings in isolated islets $24 \mathrm{~h}$ after a high dose of TCDD in vivo $[30,31]$. Furthermore, when human islets were exposed directly to TCDD, three of five donors had significantly lower C-peptide secretion and, on average, all donor islets secreted less C-peptide if they had been exposed to TCDD vs DMSO. Mouse islets also showed a similar response to direct TCDD treatment ex vivo. Together, these data suggest that TCDD directly affects islet function, possibly due to direct impairment of insulin secretion by beta cells or via indirect paracrine mechanisms (i.e. secretion of counterregulatory hormones). The impact of TCDD on islet physiology should be further assessed in longer-term studies at more physiologically relevant concentrations.

Exposure to dioxin-like pollutants is consistently associated with increased type 2 diabetes incidence and beta cell dysfunction in humans [24, 25, 27, 28], yet the pancreas has been largely overlooked as a potential target tissue. We show that systemic TCDD administration upregulates CYP1A1 enzymes in islets, indicating that the endocrine pancreas is directly exposed to TCDD in vivo. We expect that other dioxin-like pollutants will activate the AhR pathway in islets in a similar manner, although presumably with less potency than TCDD. The role of CYP1A1 in islets generally and beta cells specificially remains to be determined, but, at minimum, this enzyme serves as a useful biomarker for direct exposure of the endocrine pancreas to POPs in vivo.

Acknowledgements We are extremely grateful to TJ. Kieffer (UBC) for his mentorship and financial support of the experiments conducted at UBC. We also thank Z. Ao and G. Warnock from the Irving K. Barber Human Islet Isolation Laboratory (Vancouver, BC, Canada) and P. MacDonald from the University of Alberta IsletCore (Edmonton, AB, Canada) for providing human islets. Finally, we thank the following individuals from UBC for their technical assistance: R. Baker for help designing $\mathrm{qPCR}$ primers, A. Asadi for paraffin embedding human islets, S. 
Erener for guidance with islet stress experiments and T. Webber for cell culture support.

Data availability The datasets generated during and/or analysed during the current study are available from the corresponding author on reasonable request.

Funding This research was funded by a National Sciences and Engineering Research Council of Canada (NSERC) Discovery Grant to JEB (\#RGPIN-2017-06265) and the Canadian Foundation for Innovation John R. Evans Leaders Fund and Ontario Research Fund (\#37231). This work was also supported by a CIHR Foundation Grant to T. J. Kieffer (\#332793). MPH was supported by an NSERC CGS M and an Ontario Graduate Scholarship (OGS). SF and CC were funded by a Carleton University Dean's Summer Research Internship and SF also received NSERC USRA funding.

Duality of interest The authors declare that there is no duality of interest associated with this manuscript.

Contribution statement JEB and MI conceived the experimental design. All authors were involved with acquistion, analysis and interpretation of data. JEB wrote the manuscript. All authors contributed to manuscript revisions and approved the final version of the article. JEB is the guarantor of this work.

Open Access This article is distributed under the terms of the Creative Commons Attribution 4.0 International License (http:// creativecommons.org/licenses/by/4.0/), which permits unrestricted use, distribution, and reproduction in any medium, provided you give appropriate credit to the original author(s) and the source, provide a link to the Creative Commons license, and indicate if changes were made.

\section{References}

1. McGoldrick DJ, Murphy EW (2016) Concentration and distribution of contaminants in lake trout and walleye from the Laurentian Great Lakes (2008-2012). Environ Pollut 217:85-96. https://doi. org/10.1016/j.envpol.2015.12.019

2. Hung H, Katsoyiannis AA, Guardans R (2016) Ten years of global monitoring under the Stockholm Convention on Persistent Organic Pollutants (POPs): trends, sources and transport modelling. Environ Pollut 217:1-3. https://doi.org/10.1016/j.envpol.2016.05.035

3. Kumar J, Lind L, Salihovic S, van Bavel B, Ingelsson E, Lind PM (2014) Persistent organic pollutants and liver dysfunction biomarkers in a population-based human sample of men and women. Environ Res 134:251-256. https://doi.org/10.1016/j. envres.2014.07.023

4. Perkins JT, Petriello MC, Newsome BJ, Hennig B (2016) Polychlorinated biphenyls and links to cardiovascular disease. Environ Sci Pollut Res Int 23(3):2160-2172. https://doi.org/10. 1007/s11356-015-4479-6

5. Gascon M, Morales E, Sunyer J, Vrijheid M (2013) Effects of persistent organic pollutants on the developing respiratory and immune systems: a systematic review. Environ Int 52:51-65. https://doi.org/10.1016/j.envint.2012.11.005

6. Hertz-Picciotto I, Park HY, Dostal M, Kocan A, Trnovec T, Sram R (2008) Prenatal exposures to persistent and non-persistent organic compounds and effects on immune system development. Basic Clin Pharmacol Toxicol 102(2):146-154. https://doi.org/10.1111/j. 1742-7843.2007.00190.x

7. Boas M, Feldt-Rasmussen U, Main KM (2012) Thyroid effects of endocrine disrupting chemicals. Mol Cell Endocrinol 355(2):240248. https://doi.org/10.1016/j.mce.2011.09.005
8. Birnbaum LS, Tuomisto J (2000) Non-carcinogenic effects of TCDD in animals. Food Addit Contam 17(4):275-288. https:// doi.org/10.1080/026520300283351

9. Bertazzi PA, Consonni D, Bachetti S et al (2001) Health effects of dioxin exposure: a 20-year mortality study. Am J Epidemiol 153(11):1031-1044. https://doi.org/10.1093/aje/153.11.1031

10. Wang SL, Tsai PC, Yang CY, Guo YL (2008) Increased risk of diabetes and polychlorinated biphenyls and dioxins: a 24-year follow-up study of the Yucheng cohort. Diabetes Care 31(8): 1574-1579. https://doi.org/10.2337/dc07-2449

11. Vena J, Boffetta P, Becher H et al (1998) Exposure to dioxin and nonneoplastic mortality in the expanded IARC international cohort study of phenoxy herbicide and chlorophenol production workers and sprayers. Environ Health Perspect 106(Suppl 2):645-653

12. Calvert GM, Sweeney MH, Deddens J, Wall DK (1999) Evaluation of diabetes mellitus, serum glucose, and thyroid function among United States workers exposed to 2,3,7,8-tetrachlorodibenzo-pdioxin. Occup Environ Med 56(4):270-276. https://doi.org/10. 1136/oem.56.4.270

13. Yi SW, Hong JS, Ohrr H, Yi JJ (2014) Agent Orange exposure and disease prevalence in Korean Vietnam veterans: the Korean veterans health study. Environ Res 133:56-65. https://doi.org/10. 1016/j.envres.2014.04.027

14. Kim JS, Lim HS, Cho SI, Cheong HK, Lim MK (2003) Impact of Agent Orange exposure among Korean Vietnam veterans. Ind Health 41(3):149-157. https://doi.org/10.2486/indhealth.41.149

15. Henriksen GL, Ketchum NS, Michalek JE, Swaby JA (1997) Serum dioxin and diabetes mellitus in veterans of Operation Ranch Hand. Epidemiology 8(3):252-258. https://doi.org/10. 1097/00001648-199705000-00005

16. Longnecker MP, Michalek JE (2000) Serum dioxin level in relation to diabetes mellitus among Air Force veterans with background levels of exposure. Epidemiology 11(1):44 48. https://doi.org/10. 1097/00001648-200001000-00010

17. Kuo CC, Moon K, Thayer KA, Navas-Acien A (2013) Environmental chemicals and type 2 diabetes: an updated systematic review of the epidemiologic evidence. Curr Diab Rep 13(6): 831-849. https://doi.org/10.1007/s11892-013-0432-6

18. Porta M (2006) Persistent organic pollutants and the burden of diabetes. Lancet 368(9535):558-559. https://doi.org/10.1016/ S0140-6736(06)69174-5

19. Thayer KA, Heindel JJ, Bucher JR, Gallo MA (2012) Role of environmental chemicals in diabetes and obesity: a National Toxicology Program workshop review. Environ Health Perspect 120(6):779-789. https://doi.org/10.1289/ehp.1104597

20. Lee DH, Lee IK, Song K et al (2006) A strong dose-response relation between serum concentrations of persistent organic pollutants and diabetes: results from the National Health and Examination Survey 1999-2002. Diabetes Care 29(7):1638-1644. https://doi. org/10.2337/dc06-0543

21. Pal S, Blais JM, Robidoux MA et al (2013) The association of type 2 diabetes and insulin resistance/secretion with persistent organic pollutants in two First Nations communities in northern Ontario. Diabetes Metab 39(6):497-504. https://doi.org/10.1016/j.diabet. 2013.01.006

22. Everett CJ, Frithsen IL, Diaz VA, Koopman RJ, Simpson WM Jr, Mainous AG 3rd (2007) Association of a polychlorinated dibenzop-dioxin, a polychlorinated biphenyl, and DDT with diabetes in the 1999-2002 National Health and Nutrition Examination Survey. Environ Res 103(3):413-418. https://doi.org/10.1016/j.envres. 2006.11.002

23. Lee DH, Porta M, Jacobs DR Jr, Vandenberg LN (2014) Chlorinated persistent organic pollutants, obesity, and type 2 diabetes. Endocr Rev 35(4):557-601. https://doi.org/10.1210/er.9013-1084

24. Taylor KW, Novak RF, Anderson HA et al (2013) Evaluation of the association between persistent organic pollutants (POPs) and 
diabetes in epidemiological studies: a national toxicology program workshop review. Environ Health Perspect 121(7):774-783. https:// doi.org/10.1289/ehp.1205502

25. Roh E, Kwak SH, Jung HS et al (2015) Serum aryl hydrocarbon receptor ligand activity is associated with insulin resistance and resulting type 2 diabetes. Acta Diabetol 52(3):489-495. https:// doi.org/10.1007/s00592-014-0674-Z

26. Lee YM, Ha CM, Kim SA et al (2017) Low-dose persistent organic pollutants impair insulin secretory function of pancreatic $\beta$-cells: human and in vitro evidence. Diabetes 66(10):2669-2680. https:// doi.org/10.2337/db17-0188

27. Jorgensen ME, Borch-Johnsen K, Bjerregaard P (2008) A crosssectional study of the association between persistent organic pollutants and glucose intolerance among Greenland Inuit. Diabetologia 51(8):1416-1422. https://doi.org/10.1007/s00125-008-1066-0

28. Dirinck EL, Dirtu AC, Govindan M, Covaci A, Van Gaal LF, Jorens PG (2014) Exposure to persistent organic pollutants: relationship with abnormal glucose metabolism and visceral adiposity. Diabetes Care 37(7):1951-1958. https://doi.org/10.2337/dc13-2329

29. Mailloux R, Fu A, Florian M et al (2015) A Northern contaminant mixture impairs pancreas function in obese and lean JCR rats and inhibits insulin secretion in MIN6 cells. Toxicology 334:81-93. https://doi.org/10.1016/j.tox.2015.06.001

30. Novelli M, Piaggi S, De Tata V (2005) 2,3,7,8-Tetrachlorodibenzop-dioxin-induced impairment of glucose-stimulated insulin secretion in isolated rat pancreatic islets. Toxicol Lett 156(2):307-314. https://doi.org/10.1016/j.toxlet.2004.12.004

31. Kurita H, Yoshioka W, Nishimura N, Kubota N, Kadowaki T, Tohyama C (2009) Aryl hydrocarbon receptor-mediated effects of TCDD on glucose-stimulated insulin secretion in mice. J Appl Toxicol 29:689-694

32. Wells PG, Lee CJJ, McCallum GP, Perstin J, Harper PA (2010) Receptor- and reactive intermediate-mediated mechanisms of teratogenesis. In: Uetrecht J (ed) Adverse drug reactions. Handbook of Experimental Pharmacology, vol 196. Springer, Berlin, Heidelberg

33. Nebert DW, Roe AL, Dieter MZ, Solis WA, Yang Y, Dalton TP (2000) Role of the aromatic hydrocarbon receptor and $[\mathrm{Ah}]$ gene battery in the oxidative stress response, cell cycle control, and apoptosis. Biochem Pharmacol 59(1):65-85. https://doi.org/10. 1016/s0006-2952(99)00310-x

34. Ma Q, Lu AY (2007) CYP1A induction and human risk assessment: an evolving tale of in vitro and in vivo studies. Drug Metab Dispos 35(7):1009-1016. https://doi.org/10.1124/dmd.107.015826

35. Miksys S, Tyndale RF (2013) Cytochrome P450-mediated drug metabolism in the brain. J Psychiatry Neurosci 38(3):152-163. https://doi.org/10.1503/jpn. 120133

36. Gundert-Remy U, Bernauer U, Blomeke B et al (2014) Extrahepatic metabolism at the body's internal-external interfaces. Drug Metab Rev 46(3):291-324. https://doi.org/10.3109/ 03602532.2014.900565

37. Diliberto JJ, Akubue PI, Luebke RW, Birnbaum LS (1995) Doseresponse relationships of tissue distribution and induction of CYP1A1 and CYP1A2 enzymatic activities following acute exposure to 2,3,7,8-tetrachlorodibenzo-p-dioxin (TCDD) in mice. Toxicol Appl Pharmacol 130(2):197-208. https://doi.org/10.1006/ taap. 1995.1025

38. Lai KP, Wan HT, Ng AH, Li JW, Chan TF, Wong CK (2017) Transcriptomic and functional analyses on the effects of dioxin on insulin secretion of pancreatic islets and $\beta$-cells. Environ Sci Technol 51(19):11390-11400. https://doi.org/10.1021/acs.est.7b02830

39. Clarke J, Flatt PR, Barnett CR (1997) Cytochrome P450 1A-like proteins expressed in the islets of Langerhans and altered pancreatic $\beta$-cell secretory responsiveness. Br J Pharmacol 121(3):389-394. https://doi.org/10.1038/sj.bjp.0701139
40. Kessova IG, DeCarli LM, Lieber CS (1998) Inducibility of cytochromes P-4502E1 and P-4501A1 in the rat pancreas. Alcohol Clin Exp Res 22:501-504

41. Chen YH, Tukey RH (1996) Protein kinase C modulates regulation of the CYP1A1 gene by the aryl hydrocarbon receptor. J Biol Chem 271(42):26261-26266. https://doi.org/10.1074/jbc.271.42.26261

42. Xu H, Li C, Li Y et al (2015) Generation of Tg(cypla:gfp) transgenic zebrafish for development of a convenient and sensitive in vivo assay for aryl hydrocarbon receptor activity. Mar Biotechnol (NY) 17:831-840

43. Riddick DS, Huang Y, Harper PA, Okey AB (1994) 2,3,7,8Tetrachlorodibenzo-p-dioxin versus 3-methylcholanthrene: comparative studies of $\mathrm{Ah}$ receptor binding, transformation, and induction of CYP1A1. J Biol Chem 269(16):12118-12128

44. National Institutes of Health (2006) NTP technical report on the toxicology and carcinogenesis studies of 2,3,7,8-tetrachlorodibenzo- $p$ dioxin (TCDD) in female Harlan Sprague-Dawley rats (gavage studies). NIH publication no. 06-4468. U.S. Department of Health and Human Services, Public Health Service, National Institutes of Health, Research Triangle Park. Available from https://ntp.niehs.nih.gov/ntp/ htdocs/lt_rpts/tr521.pdf. Accessed October 2019

45. Bell DR, Clode S, Fan MQ et al (2007) Relationships between tissue levels of 2,3,7,8-tetrachlorodibenzo-p-dioxin (TCDD), mRNAs, and toxicity in the developing male Wistar(Han) rat. Toxicol Sci 99(2):591-604. https://doi.org/10.1093/toxsci/kfm179

46. Dragin N, Uno S, Wang B, Dalton TP, Nebert DW (2007) Generation of 'humanized' hCYP1A1_1A2_Cypla1/1a2(-/-) mouse line. Biochem Biophys Res Commun 359(3):635-642. https://doi.org/10.1016/j.bbrc.2007.05.202

47. Uno S, Dalton TP, Sinclair PR et al (2004) Cyplal(-/-) male mice: protection against high-dose TCDD-induced lethality and wasting syndrome, and resistance to intrahepatocyte lipid accumulation and uroporphyria. Toxicol Appl Pharmacol 196(3):410-421. https://doi. org/10.1016/j.taap.2004.01.014

48. Tan BM, Zammit NW, Yam AO et al (2013) Baculoviral inhibitors of apoptosis repeat containing (BIRC) proteins fine-tune TNFinduced nuclear factor kappaB and c-Jun N-terminal kinase signalling in mouse pancreatic beta cells. Diabetologia 56(3):520-532. https://doi.org/10.1007/s00125-012-2784-x

49. Kim S, Millet I, Kim HS et al (2007) NF-kB prevents $\beta$ cell death and autoimmune diabetes in NOD mice. Proc Natl Acad Sci U S A 104(6):1913-1918. https://doi.org/10.1073/pnas.0610690104

50. Maedler K, Schumann DM, Sauter N et al (2006) Low concentration of interleukin- $1 \beta$ induces FLICE-inhibitory protein-mediated beta-cell proliferation in human pancreatic islets. Diabetes 55(10): 2713-2722. https://doi.org/10.2337/db05-1430

51. Arous C, Ferreira PG, Dermitzakis ET, Halban PA (2015) Short term exposure of beta cells to low concentrations of interleukin1beta improves insulin secretion through focal adhesion and actin remodeling and regulation of gene expression. J Biol Chem 290(10):6653-6669. https://doi.org/10.1074/jbc.M114.611111

52. Papaccio G, Graziano A, D'Aquino R, Valiante S, Naro F (2005) A biphasic role of nuclear transcription factor (NF) $\mathrm{kB}$ in the islet $\beta$ cell apoptosis induced by interleukin (IL)-1 $\beta$. J Cell Physiol 204(1): 124-130. https://doi.org/10.1002/jcp.20276

53. Ehses JA, Perren A, Eppler E et al (2007) Increased number of isletassociated macrophages in type 2 diabetes. Diabetes 56(9):2356 2370. https://doi.org/10.2337/db06-1650

54. Richardson SJ, Willcox A, Bone AJ, Foulis AK, Morgan NG (2009) Islet-associated macrophages in type 2 diabetes. Diabetologia 52(8):1686-1688. https://doi.org/10.1007/s00125009-1410-z

55. Butcher MJ, Hallinger D, Garcia E et al (2014) Association of proinflammatory cytokines and islet resident leucocytes with islet dysfunction in type 2 diabetes. Diabetologia 57(3):491-501. https:// doi.org/10.1007/s00125-013-3116-5 
56. Solimena M, Schulte AM, Marselli L et al (2018) Systems biology of the IMIDIA biobank from organ donors and pancreatectomised patients defines a novel transcriptomic signature of islets from individuals with type 2 diabetes. Diabetologia 61(3):641-657. https:// doi.org/10.1007/s00125-017-4500-3

57. Chapman DE, Schiller CM (1985) Dose-related effects of 2,3,7,8tetrachlorodibenzo-p-dioxin (TCDD) in C57BL/6J and DBA/2J mice. Toxicol Appl Pharmacol 78(1):147-157. https://doi.org/10. 1016/0041-008x(85)90314-x
58. Smith AG, Clothier B, Carthew P et al (2001) Protection of the Cypla2(-/-) null mouse against uroporphyria and hepatic injury following exposure to 2,3,7,8-tetrachlorodibenzo-p-dioxin. Toxicol Appl Pharmacol 173(2):89-98. https://doi.org/10.1006/taap.2001.9167

Publisher's note Springer Nature remains neutral with regard to jurisdictional claims in published maps and institutional affiliations. 